\title{
Modern Evrim Teorisinin Muhammed İkbal'in Düşüncelerindeki Rolü Üzerine Eleştirel Bir Yaklaşım
}

Role of Modern Evolution Theory over Mohammad Iqbal's Thoughts:

\author{
A Critical Approach
}

\section{Osman DEMİRCi}

Dr. Öğr. Üyesi, Trabzon Üniversitesi, İlahiyat Fakültesi, Trabzon/Türkiye Assistant Professor Dr., Trabzon University, Faculty of Theology, Trabzon/Türkiye

osman.demirci@windowslive.com | orcid.org/0000-0002-0620-6670

$\begin{aligned} \text { Makale Bilgisi } & \text { Article Information } \\ \text { Makale Türü } & \text { Article Type } \\ \text { Araştırma Makalesi } & \text { Research Article } \\ \text { Geliş Tarihi } & \text { Date Recieved } \\ 13 \text { Ekim 2021 } & 13 \text { October 2021 } \\ \text { Kabul Tarihi } & \text { Date Accepted } \\ 21 \text { Aralık 2021 } & 21 \text { December } 2021 \\ \text { Yayın Tarihi } & \text { Date Published } \\ 31 \text { Aralık 2021 } & 31 \text { December 2021 } \\ \text { İntihal } & \text { Plagiarism } \\ \text { tespit edilmemiştir. } & \text { software. No plagiarism detected. } \\ \text { Etik Beyan } & \text { Ethical Statement } \\ \text { Bu makale, iTenticate yazılımı ile taranmıstır. İntihal } & \text { This article has been scanned with iTenticate } \\ \text { Bu çalışmanın hazırlanma sürecinde bilimsel ve etik } & \text { It is declared that scientific and ethical principles } \\ \text { ilkelere uyulduğu ve yararlanılan tüm çalışmaların } & \text { have been followed while carrying out and writing } \\ \text { kaynakçada belirtildiği beyan olunur (Osman } & \text { this study and that all the sources used have been } \\ \text { Demirci). } & \text { properly cited (Osman Demirci). } \\ \text { CC BY-NC-ND 4.0 lisansı ile lisanslanmıştır. } & \text { Licensed under CC BY-NC-ND 4.0 license. }\end{aligned}$

Atıf | Cite As

c Demirci, Osman. "Modern Evrim Teorisinin Muhammed İkbal'in Düşüncelerindeki Rolü Üzerine Eleştirel Bir Yaklaşım”. Kader 19/2 (Aralık 2021), 727-756. https://doi.org/10.18317/kaderdergi.1008861 


\section{Öz}

Bu makalede, i̇kbal'in modern evrim teorisini kendine özgü yorumlaması, bu teorinin onun düşünce sistemindeki etkileri, inanç ve ahlâkî değerlerin bu teoriyle nasıl uzlaştırılmaya çalışıldığı ve bütün bunların arasında İkbal'in tutarlılı̆̆ sağlayıp sağlayamadığı ele alınmaya çalışılacaktır. İkbal'in yaratıcı evrim teorisi eleştirel bir açıdan irdelenmektedir. İkbal'in geçmişteki Müslüman düşünürlerden ve modern dönem Batılı düşünürlerden hangi ölçüde etkilenmiş olduğu yine onun eserlerinden yola çıkılarak karşılaştırmalı olarak ele alınmaktadır. Din-bilim krizinin belirgin bir şekilde görüldüğü evrim teorisi konusunda İkbal'in tercihleri ve yapmaya çalşstı̆̆ sentezci düşünceye dikkat çekilmekte, İkbal'in bu teori bağlamında inanç konularında getirmiş olduğu yeni yorumlar üzerinde durulmakta, íkbal'in ahlâk felsefesinin de yine bu teori bağlamında nasıl şekillendiği gösterilmeye çalışılmaktadır. İkbal'in metafizik bir içerikle modern evrim teorisini kendine özgü yorumlamasının etkileri, onun bütün düşüncelerine sirayet etmiştir. Düşünür evrim teorisinden kaynaklanan bu düşünceleri dolayısıyla eleştirilmektedir. Onun görüşlerinde kendi döneminin bilimsel ve felsefî gelişmelerin etkisi olduğu gibi Müslüman coğrafyanın içinde bulunduğu durumun da etkisi vardır. Yaratıcı evrim teorisinin yaşama uyarlanmasında pratik faydalar görmekte ve bu teorinin Müslüman toplumları uyandırıcı etkisinin olduğuna inanmaktadır. Söz konusu evrim teorisi güce ve mücadeleci yaşam felsefesine yaptığı güçlü vurguyla İkbal'in ilgisini çekmiş olmalıdır. İkbal için yaşam bir mücadele olarak görüldüğünden insanın başarı ve mutluluğu da bu hayat mücadelesindeki sertliğine bağlanmakta ve bu vurgu, değişik vesilelerle ve farklı bağlamlarla sürekli tekrar edilmektedir. Ona göre hayat bir kavgadır ve bu yaşam kavgasında başarılı olanlar bu kurallara riayet edenlerdir. Evrim teorisine uygun olacak şekilde düşünür, hak ve bâtılı dahi güce göre ayırmakta ve güçle haklıllı̆̆ eşit görmektedir. Evrimsel sürecin ebedî hayat için de geçerli olan bir kanun olarak görülmesiyle bu teoriye metafizik bir anlam yüklenmekte ve bilimsel tartışmalara girilmemektedir. Evrim teorisi, İkbal'in ego felsefesinin, Tanrı-âlem-insan görüşünün de bilimsel ve felsefî temelini oluşturmaktadır. Ahiret hayatı, nübüvvet, irade özgürlüğü gibi birçok teolojik mesele bu teori bağlamında yorumlanmaya çalışılmaktadır. İkbal, evrim teorisiyle dini uzlaştırmak adına bazen dinî nasları te'vil etmekte, bazen de evrim teorisine metafizik bir anlam yükleyerek yeniden yorumlamaktadır. Evrim teorisini düşüncelerine bilimsel bir zemin olarak koyan düşünürün tutarsızlıklarının en önemli nedenlerinden birisi de onun yapmaya çalıştığı bu sentezci çabadır. İkbal, evrim teorisi konusunda geçmişteki Müslüman bilginlerden İbn Miskeveyh ve Mevlânâ'dan; modern dönem Batılı bilginlerinden ise özellikle Bergson ve Nietzsche'den etkilenmiştir. Onun modern evrim teorisine en temel itirazı ise bu kuramın hükmünün yaşamla sınırlı olması ve ölüm sonrasına aksetmemesidir.

Anahtar Kelimeler: Kelâm, Bilim, Evrim teorisi, Darwinizm, Muhammed İkbal.

\section{Abstract}

In this article, Iqbal's unique interpretation of the modern theory of evolution, the effects of this theory on his system of thought, how belief and moral values are tried to be reconciled with this theory, and whether Iqbal can provide consistency among all these will be discussed. Iqbal's theory of creative evolution is critically examined. The extent to which Iqbal was influenced by the Muslim thinkers of the past and the Western thinkers of the modern period is discussed comparatively, again based on her works. Attention is drawn to Iqbal's choices and the synthesist thought he tried to make on the theory of evolution, in which the crisis of religion-science is clearly seen, new interpretations of Iqbal's belief in the context of this theory are emphasized, and how Iqbal's moral philosophy was shaped in the context of this theory is being displayed. The effects of Iqbal's unique interpretation of the modern theory of evolution with a metaphysical content permeated all her thoughts.The philosopher is criticized for these thoughts stemming from the theory of evolution. His views are influenced by the scientific and philosophical developments of his time, as well as the situation in the Muslim geography. He sees practical benefits in adapting the theory of creative evolution to life and believes that this theory has a stimulating effect on Muslim societies. The theory of evolution in question must have caught Iqbal's attention with its strong emphasis on power and a combative philosophy of life. Since life is seen as a struggle for Iqbal, the success and happiness of man is also tied to his hardness in this struggle for life, and this emphasis is constantly repeated on different occasions and in different contexts. According to his point of view, life is fight and those who are successful in this fight for life are those who follow these rules. He thinks in accordance with the theory of evolution, distinguishes between right and wrong considering power and sees power and rightness as equal. Considering the evolutionary process as a law that is also valid for eternal life, a metaphysical meaning is attributed to this theory and scientific debates are not got to the point. The theory of evolution forms the scientific and philosophical basis of Iqbal's ego philosophy and his view of God-realm-human. Many theological issues such as life in the hereafter, prophecy, freedom 
of will are tried to be interpreted in the context of this theory. In order to reconcile the theory of evolution with religion, Iqbal sometimes interprets religious texts and sometimes reinterprets the theory of evolution by giving it a metaphysical meaning. One of the most important reasons for the inconsistency of the philosopher, who put the theory of evolution as a scientific basis for his thoughts, is this synthesist effort he attempted to create. Iqbal He was influenced by former Muslim scholars Ibn Maskeveyh and Mevlana on the theory of evolution as well as modern Western scholars, especially Bergson and Nietzsche. His basic objection to the modern theory of evolution is that the provision of this theory is limited to life and does not reflect on after death.

Keywords: Kalam, Science, Theory of evolution, Darwinism, Muhammad Iqbal.

\section{Giriş}

İnsan dâhil, canlıların bütün çeşitliğiyle ilksel birkaç türden türemekte olduğunu, madde de belirsiz ve tutarsız bir yapıdan, tutarlı ve belirli çok yapılılığa ulaştığını ihtiva eden evrim teorisinde ${ }^{1}$, Darwin'e göre bir varolma savaşı içinde olan canlılar dünyasında ${ }^{2}$ doğal seçilim ilkesine göre en uygun olanlar hayatta kalmaktadır. ${ }^{3}$ Darwin'den asırlar önce Müslümanlar düşünürlerin modern evrim teorisinin öncülleri olduğu iddia edilmekte, modern anlamda evrim fikrini ortaya ilk atanın, meşhur Mu'tezilî kelâmcı Nazzâm (ö. 231/845) olduğư ${ }^{4}$, onun konu hakkındaki fikirlerinin öğrencisi Câhiz tarafından geliștirildiğ ${ }^{5}$, İhvânu's-Safâ, İbn Miskeveyh (ö. 421/1030), Bîrûnî (ö. 453/1061 [?]) ve İbnü’l-Heysem (ö. 432/1040 [?]) gibi Müslüman düşünürlerin canlıların biyolojik evriminden bahsettikleri ileri sürülmüştür. ${ }^{6}$ Ebû Bekir er-Râzînnin (ö. 313/925) denek olarak hastalarını değil de maymunları kullanmış ve deneylerini onların üzerinde

Afşin Timuçin, “Evrim”, Felsefe Sözlüğü (İstanbul: Bulut Yayınları, 2002), 209.

Charles Darwin, Türlerin Kökeni, çev. Öner Ünalan (İstanbul: Evrensel Basım Yayınları, 2009), 88-89.

Darwin, Türlerin Kökeni, 107-120.

4 Nazzâm'ın Kümûn-Zuhûr teorisi, XVIII. yüzyılda Londralı Doktor Cheyne tarafından da teyid edilmektedir. Bu teoriye göre şu anki durumlarıyla zamanın başlangıcında yaratılan hayvan ve bitkiler, zamanı geldiğinde sahneye çıkacaklardı. (Stephen F. Mason, Bilimler Tarihi, çev. Umur Daybelge (Ankara: Türk Tarih Kurumu Yayınları, 2013), 288-289). Mu'tezilî düşünür Câhiz, canlıların hayatındaki göçlerin ve çevrenin neden olduğu değişimlere ilk dikkat çeken düşünürdür. İhvân-1 Safâ olarak tanınan topluluk, Câhiz'ın evrim düşüncesini daha da genişletmişse de insanın kaynağı hakkında daha bütüncül, açık ve modern teoriyi İbn Miskeveyh (ö. 421/1030) ortaya koymuştur. Buna göre hayvanın ufuk çizgisi maymundur ve onun aşılmasıyla insana ulaşılır. Dahası, insanların aralarında da evrimsel bir hiyerarşi mevcuttur. İlk gelişim aşamasında zayıf bir ayırt etme gücü olan insanın henüz düşünme gücü gelişmemiş olduğundan dolayı bu ilkel insanların, hayvanlığın son mertebeleriyle aralarında bir farkı yoktur. İnsanların düşünme gücü artmasıyla evrimsel süreç insan açısından devam eder. İnsan duyu gücünden muhayyile gücüne, oradan düşünme gücüne ve en son olarak da ilahi varlıkların hakikatini anlamak düzeyine ulaşır. Filozoflar ve peygamberler bu son mertebede olsalar da onların dahi aralarında farklar vardır (Mahmut Kaya, İslâm Filozoflarından Felsefe Metinleri (İstanbul: Klasik Yayınları, 2003), 256-260).

5 Aslında Câhiz, insanla maymun arasındaki gerek fiziksel gerekse ahlâksal benzerliğe dikkat çekmişse de insanın maymundan evrildiğine veya maymun ve insanın ortak bir atadan geldiğine herhangi bir gönderme yapmamakta, sadece insanın maymuna dönüşmesinin imkânından bahsetmektedir (Yunus Cengiz, Doğa ve Öznellik Câhiz’in Ahlâk Düşüncesi, İstanbul: Klasik Yayınları, 2015), 56).

6 Bayrakdar, İslâm'da Evrimci Yaratılış Teorisi, 14-16. Fakat bu yaklaşımı doğru bulmayan araştırmacılar da vardır. Taslaman'a göre İslâm düşünürlerinin evrime dair imaları Lamark ve Darwin tarafından ortaya konan ve her canlının başka bir türün değişimiyle oluştuğu kuramına ne temeldir ne de önceden bir sezinlemedir. Bununla birlikte Taslaman, İslâm düşünürlerinin varlığın mertebeleriyle ilgili görüşlerinin söz konusu evrim teorisinin iddialarıyla alakası olmadığını söylese de bazı İslâm düşünürlerinin doğal seleksiyon ve dönüşümcülük fikrine gönderme yapmış olmalarını ve evrim teorisine katkılarının olabileceğini kabul edecektir (Caner Taslaman, Evrim Teorisi Felsefe ve Tanrı (İstanbul: İstanbul Yayınevi, 2009), 35-37). 
yapmıştır.7 Bununla birlikte Müslüman düşünürlerin modern bilimsel evrim teorisinin öncüllüğünü yapan bir evrimden değil, metafizik ilkelere bağlı olan bir varlıklar düzeninden ve varlığın bütünlüğ̈̈nden bahsettikleri ileri sürülerek birçok açıdan modern evrim teorisi eleştirilecektir. ${ }^{8}$

Modern evrim teorisi Batı'da olduğu gibi Müslüman coğrafyada yoğun tartışmalara neden olmuştur. ${ }^{9}$ Müslüman düşünürler arasında bu teoriye kesinlikle karşı olanların yanında, ${ }^{10}$ aklen mümkün görmekle birlikte şüpheyle yaklaşanlar ve din açısından bir sorun oluşturmadığını ileri sürerek bu teoriyi kabul edenler de bulunmaktadır. Evrim teorisinin dinle çatışmayacağını kabul edenler arasında Seyyid Ahmed Han'ı (1817-1898), Muhammed Abduh'u (1849-1905), Süleyman Ateş'i, Muhammed Hamidullah'ı (1908-2002) ${ }^{11}$ ve Şiblî Nu 'mânî'yi (1857-1914) sayabiliriz. ${ }^{12}$ Evrim teorisi, Muhammed İkbal'in (1877-1938) düşünce sisteminde belirleyici bir rol oynamaktadır. İkbal daha doktora tezinde İbn Miskeveyh'in Evrim Teorisini, Şiblî̀nin İlm-i Kelâm isimli eserinden aktarmaktadır. İbn Miskeveyh felsefesi bağlamında ele alınan evrim teorisi ${ }^{13}$ İkbal'in ilgisini çekmeye devam etmekte ve İkbal, Mevlânâ'yı da modern evrim teorisinin habercisi olarak değerlendirmektedir. ${ }^{14}$ Evrim teorisi, İkbal'in ego ${ }^{15}$ felsefesinin, Tanr1-âlem-insan görüşünün de

\footnotetext{
Kaya, İslâm Filozoflarindan Felsefe Metinleri, 70.
}

Bk. Fevzi Yiğit, Metafizik ve Evrim, İstanbul: Önsöz Yayıncılık, 2021, 33vd.

Osmanlı toplumunda evrim teorisi ilk defa 1872 tarihinde Ahmed Midhat Efendi (ö. 1844-1912) tarafından gündeme taşınmıştır. Evrim teorisinin batıda tartışıldığı dönemde Türkiye'de konuyla alakalı olarak "Dağarcık”ta Ahmed Midhat Efendi, insanın oluşumunu evrim teorisine göre ele alan makaleler yazmış ve buradaki düşüncelerinin Kur'an'a aykırı olmadığını iddia etmiştir. Onun "İnsanın Dünyada Zuhuru” adlı makalesinde evrim teorisini Lamarck'a dayandırmış, insanla maymun arasındaki ilişkiye değinmiş, yaşam koşullarına bağlı olarak maymunun insana evrildiğini ve insanın da bir tür maymun olduğunu söylemiştir. Yalnız onun bu cesur çıkışı ulemâ tarafından yoğun bir eleştiriye uğramıștır (Adıvar, Tarih Boyunca İlim ve Din, 368-369). Osmanlı zamanında "maymun meselesi” olarak şöhret olan evrim teorisi konusundan bahsetmek resmen yasaklanmış, Darwin'in Türlerin Kökeni adlı eseri ancak 1970'de Türkçeye çevrilmiştir (Darwin, Türlerin Kökeni, 11-12).

10 Mesela Bilmen, hayal ve tahmine dayalı olduğunu iddia ettiği bu teoriyi bilimsel bir teori olarak görmemekte ve âyet ve hadislerin buna göre te'vil edilmesine cevaz vermemektedir (Ömer Nasuhî Bilmen, Muvazzah ílm-i Kelâm (İstanbul: Ravza Yayınları, 2013), 198-201). Modern evrim teorisinin bilimsel olmayan bir faraziye olduğu yönünde Osmanlı son dönem kelâmcıları arasında bir görüş birliği var gibidir. İzmirli İsmail Hakkı (1869-1946), Mustafa Sabri (1869-1954) ve Filibeli Ahmed Hilmi (1865-1914) gibi kelâmcılar bu teoriye sıcak bakmazlar (bk. Rabiye Çetin, “Tanzimat'tan Günümüze Kelâm'ı Yenileme Çalışmaları I”, Dini Araştırmalar 16/42 (Ocak-Haziran 2013), 25-30). Bunda özellikle Osmanlı toplumunda inançsız Aydınların bu teoriyi inançsızlı̆ı̆ı bilimsel zemini olarak kullanmalarının payı önemlidir. Bu konuyu ele alan bir çalışma için bkz. Atila Doğan, Osmanlı Aydınları ve Sosyal Darwinizm (İstanbul: Küre Yayınları, 2005).

11 Bayrakdar, İslâm'da Evrimci Yaratillş Teorisi, 17-20.

12 Mehmet Sait Özervarl, Kelâmda Yenilik Hareketleri (İstanbul: İSAM Yayınları, 1998), 82.

13 Muhammed İkbal, İslâm Felsefesine Bir Katkı İran'da Metafizik İlimlerin Tekâmülü, çev. Cevdet Nazlı (İstanbul: Külliyat Yayınlar1, 2017), 50-51.

14 İkbal, İslâm Felsefesine Bir Katkı, 111-112.

15 Benlik, kişilik, şahsiyet, Nefsolarak olarak karşımıza çıkan "ego" kavramının İkbal felsefesinde çok ayrı bir önemi vardır. i̇kbal, Hallâc-1 Mansûr'un (ö. 309/922) ene'l-hak "ben hakkım” ifadesini, insan benliğini takdir edemeyen, insan şahsiyetini anlayamayan ve onu sıradan bir araz seviyesine indiren kelâmcllara yönelikbir çığlık, bir meydan okuma olarak değerlendirmektedir. Egonun bazı kelâm okullarınca basit, bölünemez ve değişmez nefs-cevher olarak değerlendirilmesi de ona göre egoyu sadece metafizik yönden ele almakta ama psikolojik yönünü ihmal etmekteydiOna göre bir ego olarak insan, Allah tarafından halife olarak seçilmiş dağların reddettiği emanet olan şahsiyeti kabul eden biricik varlıktır. Fakat bu biricik olmak egoların gelişmek için bir çatışma içine girmesine ve acı çekmelerine engel değildir (Muhammed İkbal, İslâm'da Dinî Düşüncenin Yeniden İnşast, çev. Rahim Acar (İstanbul: 
bilimsel ve felsefî temelini oluşturmaktadır. İkbal, evrim teorisiyle dini uzlaştırmak adına bazen dinî nasları te'vil etmekte, bazen de evrim teorisine metafizik bir anlam yükleyerek yeniden yorumlamaktadır. Onun eliyle evrim teorisi metafizik bir bakışla sunulmakta ve bilimsel tartışmalara girilmemektedir. İkbal evrim teorisi bağlamında geçmiş Müslüman düşünürlere atıflar yaparak meşruiyet sorununu aşmaya çalışmaktaysa da onlara da bağlı kalmamaktadır. Kendi yaratıcı evrim teorisini düşüncelerine bilimsel bir zemin olarak koymaktadır. Biyolojik evrim tartışmasına pek dâhil olmak istemeyen düşünür daha çok evrim teorisinin bütün bir hayata akseden sonuçlarıyla alâkadardır. İkbal, modern biyolojik evrim teorisinin bilimsel kesinliği konusunda bir şüphesi yoktur ve bu teoriyi bilimsel bir realite olarak kabul etmekte bir sakınca görmemektedir. Onun yaptığı modern biyolojik evrim teorisini metafizik bir içerikle birey ve toplumla ilişkilendirerek ve tamamen kendi özgü bir muhtevayla yeniden ortaya koymak tır ki bu anlamda düşünür evrim teorisi karşısında pasif bir kabullenmenin ötesinde aktif bir rol oynamakta ve teoriyi yeniden yorumlamaktadır. Evrim onun nazarında temelde biyolojik olmak üzere sosyal alana ve en nihayetinde metafizik alana taşan yönüyle hayatın ve varlığın heyecan veren coşkusunu ortaya koymuştur. Bütün bunlarla birlikte biyolojik evrim teorisinin ve tekâmül sürecinin hayatla sınırlandırılmasında insanları hayal kırıklı̆ı̆ına ve kötümserliğe iten bir eksiklik olduğu kanaatindedir. Biyolojik evrim teorisine yönelik bu itirazın bilimsel değil, duygusal bir itiraz olduğunun İkbal de farkındadır. İkbal'in evrim teorisinin biyolojik yönünden çok sosyal ve psikolojik tarafı ilgisini cezbetmekte ve yaşadığı dönemde Müslüman toplumların tekrar ayağa kalkması için bu teoride diriltici bir güç tasavvur etmektedir. Düşünür-şair düşüncelerinde evrim teorisini büyük bir zevk ve heyecanla kullanmaktadır. Güç, hareket, mücadele, sonu gelmeyen var olma savaşları, gelişme, ilerleme, büyüme, arzu duyma, acı çekme, yaşamın coşkusunu her daim hissetme, bu teori bağlamında İkbal'in öne çıkardığı kavramlar evrenidir ve kendi yaşamı da bu coşkunun vücud bulmuş hâlidir, bir parçasıdır. İkbal, evrimsel düşünceden doğan bu dinamik yaşam felsefesinin izini sürerken meseleyi daha çok mistik ve metafizik bir boyuta çekmekte ve geleneksel mistik ve metafizik söylemlerle modern dönem evrim düşüncesini sentezlemeye çalışmaktadır.

\section{Evrim Teorisi Konusunda Müslüman ve Batılı Düşünürlerin Muhammed İkbal Üzerindeki Etkileri}

Muhammed İkbal bir düşünür olarak gerek Doğu'dan gerekse Batı'dan birçok düşünürden

Timaş Yayınları, 2014), 121-135). İkbal bu ego anlayışını Tanrı dâhil (Nihaî Ego) bütün bir varlığa şamil kılmıştır. Fakat Tanrı diğer egolardan farklı olarak bir gelişme amacı gütmeyecek kemâl noktasındadır. Şair-düşünür egonun da bireyin de tam olarak anlaşılmasının güçlüğünün farkındadır ve Bergson'a referansla açıklama çabasına girmektedir (ìkbal, İslâm'da Dinî Düşüncenin Yeniden İnşası, 95-96). Daha sonra İkbal, tam da evrim teorisindeki mücadele anlayışına uygun olarak egonun hayatının çevreye, çevrenin de tepkisel bir şekilde egoya saldırmasından doğan bir gerilim olarak görecektir. Dolayısıyla şahsiyet bir şey değil, bir eylemdir, fiiller sistemidir (ìkbal, İslâm'da Dinî Düşüncenin Yeniden İnşası, 136-140). Onun en büyük ego olan Tanrı'yla beraber atomdan insana birer ego olan diğer varlıkları da şahsiyetlerini Tanrı'nın varlığında koruyan birer gerçek varlık olarak değerlendirmesi, özellikle panteist ve vahdeti- vücudçu Tanrı tasavvurlarındaki diğer bütün egoları Tanrı'nın egosunda yok eden anlayışlara yönelik itirazlar olarak da görülebilir. Birer şahsiyet olan bu egoların en büyük egoyla birleşmek gibi bir amaçlarıolmaksızın şahsiyetlerini kaybetmeden kendisinden daha yüksekte olan bir ego haline gelmek için en iyi olanların galip gelecekleri daimî bir mücadele içinde oldukarını düşünmektedir. bk. Muhammed İkbal, Câvidnâme, çev. Annemarie Schimmel (İstanbul: Kırkambar Yayınları, 1999), 29-31. 
etkilenmekte ve kendi düşünce sistemini bir sentez olarak inşa etmeye çalışmaktadır. ìkbal, Kur'an'ın ruhuna da uygun bulduğu evrim teorisinde kendi düşüncesi açısından birçok imkân görmekte, bu teoriye Kur'an'dan kanıtlar aramakta ve bu teorinin meşruiyetini göstermek adına Müslüman düşünürlere sıkça atıflarda bulunmakta, evrim teorisinden bahseden Müslüman düşünürlerin varlığını Müslümanlardaki bilimsel düşüncenin erken uyanışının kanıtı olarak değerlendirmektedir. ${ }^{16}$ Ona göre Müslümanlar arasında matematik düşünceyle beraber evrim düşüncesi de aşamalı olarak gelişmiştir. İkbal, özellikle İbn Miskeveyh'in evrim düşüncesini ayrıntılı olarak da ele alarak onun evrim anlayışının modern dönem evrim düşüncesiyle olan benzerliğine dikkat çekecek, İbn Haldun'un tarih anlayışını da buna göre değerlendirecektir. ${ }^{17} \mathrm{ibn}$ Miskeveyh'in metafizik evrim teorisiyle modern evrim teorisini ilintilendirmek oldukça zordur. Öncelikle filozof, insanı hayvandan kesin bir şekilde ayrı ve üstün bir varlık olarak görmekte, ${ }^{18}$ değişimin aklî varlıklarda değil, sadece duyusal varlıklarda (sûrette) olacağını ileri sürmekte ${ }^{19}$ ve varlıklar arasında metafizik bir hiyerarşi kurmaktadır ki ( Tanrı-akıl-nefs-felek-cisim) ${ }^{20}$ bu durum onun metafizik temelli evrim anlayışının modern biyolojik evrimle irtibatını kurmanın ne denli bir zorlama olduğunu göstermektedir. İkbal'in ondan etkilendiği en önemli nokta, dinamik yaşam felsefesini ve evrim düşüncesini destekleyecek şekilde, harekete verdiği önem, hareketin bütün varlıktaki mükemmelliğe ulaşma arzusunun olduğuna ilişkin mistik düşünceleri ${ }^{21}$ olmalıdır. Filozofun varlıktaki hareketi mistik bir arzuya bağlaması İkbal'i hayli heyecanlandırmış olmalıdır. İkbal, İbn Miskeveyh'in evrim görüşünden etkilense de onun evrim teorisi kendine özgüdür ve bu konuda filozoftan farklı düşünmektedir. İbn Miskeveyh'in varlıklar hiyerarşisinde bütün üstünlüğüne rağmen insanın da evrimsel gelişiminde duracağı bir kemâl noktası vardır. Onun "ilahi olanın salt dinginlik olduğu ve insanın nihaî hedefinin de bu ilahi dinginlikle birleşmek olduğu" görüşü̈, ${ }^{22}$ Ikkbal'in süreklilik anlayışıly bağdaşmaz. İbn Miskeveyh'in hareket ve dinginliği birbirinin karşısına koyarak dinginlikte bir kemâl ve ilahîlik görmesi, İkbal'e oldukça yabancı bir düşüncedir. Oysa onun ego felsefesindeki yaşam coşkusu, insanın arzularının sürekliliğine bağlanmıştır. İnsanda arzunun sönmesi, hareketin bitmesi anlamına gelmektedir ki bu durum, insanın kemâlâtı değil, olsa olsa ölümüdür. ${ }^{23}$ Hayat, hareketten ibaret olduğuna göre bu hayat yürüyüşünde durup dinlenmek isteyenler ayaklar altında ezilmeye mahkûmdur. ${ }^{24}$

Mevlânâ'yı modern biyolojik evrimin habercisi olarak gören İkbal, Mevlânâ'nın modern evrim teorisine katkısının olabileceğine inanmaktadır. Ona göre modern evrim teorisinde insan evriminin ölümle sonlandırılması, insanlarda hayat coşkusunun yitimine ve ümitsizliğe yol

16 Muhammed İkbal, İslâm'da Dinî Düşüncenin Yeniden İnşası, 223-225.

17 İkbal, İslâm'da Dinî Düşüncenin Yeniden İnşası, 170-176.

18 İbn Miskeveyh, el-Fevzü̉-Asğar, çev. Emrah Alagaş - Mehmet Zahit Sezer (İstanbul: Endülüs Yayınları, 2020), 28, 60, 91.

19 İbn Miskeveyh, el-Fevzü'l-Asğar, 28-31.

20 İbn Miskeveyh, el-Fevzü'l-Asğar, 51-53.

21 İbn Miskeveyh, el-Fevzü'l-Asğar, 35-37.

22 Kaya, İslâm Filozoflarından Felsefe Metinleri, 261-267.

23 "Arayış zevki kalmazsa, daimi bir konfor ölümdür/Bu yolda konaklamak uygun değildir, duraklamakta ecel gizlidir." (Muhammed İkbal, Hareket Zili, çev. Celal Soydan, 2. Baskı (Ankara: Hece Yayınları, 2019), 96-101).

24

İkbal, Hareket Zili, 101. 
açmıştır. ${ }^{25}$ Modern evrim teorisindeki bu eksiklik Mevlânâ'nın yorumuyla giderilecektir. Buna göre cansızlar âleminden başlayan insanın evrim süreci, sırasıyla bitkiler ve hayvanlar âleminden geçmiş ve insan aşamasına gelmiştir, insan her ölümle daha yüksek bir hayatla dirilmiştir. İnsanın ölümden korkması için bir neden yoktur. Daha önceki hayat aşamalarını hatırlamadığı gibi insan aşamasından sonra da daha yüksek bir varoluşla tekrar hayat bulacaktır. ${ }^{26}$ ikbal, yaşamdaki çatışmanın coşkusunu ve realitesini, Mevlânâ'daki şu beyitlerine atıfla ispatlamaya çalışmaktadır:

Göğün altında insan insanı yemiştir,

Millet, başka millet üzerinde otlamıştır. ${ }^{27}$

Oysa Halife Abdülhakim'e göre varlığı ruhsal bir temele dayandıran, maddede hayat gören, her varlığın Allah'tan zuhur ettiği için ona dönme çabası içerisinde olduklarını dile getiren Mevlânâ'nın evrim düşüncesi, biyolojik ve maddeci evrim telakkisine uzaktır. Mevlânâ'ya göre de bütün nefisler veya monadlar ( Leibniz'in (1646-1716), monadları) ilahî ilkeden zuhur etmiştir. Aşk prensibine uygun olacak şekilde her nefis kendini gerçekleştirmektedir ve hepsinin ortak amacı aslına dönmektir. Onun evrim anlayışı Darwin ve Spencer'in ( 1820-1903) mekanik ve biyolojik evrim anlayışına değil, daha çok Bergson'un (1859-1941) yaratıcı evrim anlayışına benzese de Bergson'un amaçsız evrim anlayışıyla da bağdaşmayacaktır. Mevlânâ'nın evrim görüşünün maddeci ve biyolojik evrimcilerin görüşlerini de kuşatan bir tarafı vardır. Mevlânâ'ya göre hayat, maddeden tekâmül etmiş, evrimsel süreç, madde, bitki ve hayvan aşamalarından geçerek insan aşamasına ulaşmıştır. ${ }^{28}$ Netice itibariyle onun evrim anlayışı burada modern biyolojik evrimle radikal bir şekilde ayrışmakta, evrimsel sürecin ölümden sonra da devam ettiğine ve insanın ölümle bir üst varlık aşamasına ulaştığına inanılmaktadır.

İkbal'in Paris'e kendisiyle tanışmak için gittiği ${ }^{29}$ Bergson'nun düşüncelerinden oldukça etkilenmişse de ${ }^{30}$ Bergson'un, Darwin'in ve yeni Lamarck'çı (1744-1829) evrimcilerin tezlerine yaptığı bilimsel eleştiriler sonrasında kendi tekâmül nazariyesi olan hayat hamlesi (elan vital) tezini geliştirmesi ${ }^{31}$ gibi bilimsel çabalar İkbal'de görülmez. Halife Abdülhakim'in de ifade ettiği gibi İkbal maneviyatçıllğının yanında yaratıcı evrimcidir. Tek Tanrıya inandığı için teist, Mevlânâ ve Bergson ${ }^{32}$ gibi bütün varlığın müstakil benlerden oluştuğunu düşündüğü için de monadolist

25 İkbal, İslâm'da Dinî Düşüncenin Yeniden İnşası, 226-227.

26 İkbal, İslâm'da Dinî Düşüncenin Yeniden İnşası, 156-157. Mevlânâ'nın bu mistik düşüncelerini evrim lehine kullanan sadece İkbal değildir, son dönemin önemli kelâmcılarından Şibli Nümanî de onu evrim konusunda bir hareket noktası olarak kullanacaktır (Özervarlı, Kelâmda Yenilik Hareketleri, 82).

27 Annemarie Schimmel, Peygamberâne Bir Şair ve Filozof Muhammed İkbal, çev. Senail Özkan (İstanbul: Ötüken Yayınları, 2007), 212. İkbal, gençlik dönemlerinden itibaren etkilendiği Neitzsche’yi (1844-1900) Mevlânâ'yla mukayese etmekte ve filozofun egoya verdiği önem ve üstün insan arayışından etkilenmektedir (Schimmel, Muhammed İkbal, 209-210). Neitzsche'deki acıya verilen değer ve gelişmenin kaçınılmazlı̆̆ı, İkbalde de görülmektedir.

28 Halife Abdülhakim, "Mevlânâ Celâleddin Rûmî”, çev. Yusuf Ziya Cömert, İslâm Düşüncesi Tarihi, ed. M. M. Şerif Mustafa Armağan (İstanbul: İnsan Yayınları, 1990), 3/49-52.

29 Celal Soydan, İkbâl'e Dair (Ankara: Hece Yayınları, 2016), 55.

30 İkbal'in “Batının bütün felsefesini okumuş olmasına rağmen sadece Kur'an-1 Kerim ve Mevlânâ'nın Mesnevi'sinden etkilendiğini söylediğine" dair rivayetleri (Soydan, İkbâl'e Dair, 272) ihtiyatla karşılamak gerekmektedir.

31 Bk. Henri Bergson, Yaratı ı Tekâmül, çev. Mustafa Şekip Tunç (İstanbul: MEB Yayınları, 1947), 90-134.

32 Mekanizmi ve teleolojiyi reddeden Bergson'un hayat felsefesi İkbale makul gelmektedir. Buna göre hayat kozmik akıldaki belli bir plana göre akmamaktadır. Fakat İkbal ona da gerek varoluşun merkezinde bir benliğin varlığını kabul etmemesi, gerekse bu varoluşta bir amaç görmemesi açısından katılmayacak ve Bergson'u eleştirecektir. Ona 
olarak tanımlanabilir. Bütün felsefe ve sanatının amacı İslâm toplumunun canlanması ve yeniden ayağa kalkması olan şair-düşünür ${ }^{33}$, evrim teorisini de bu genel amacına uygun olarak kullanmaktadır. İkbal'in evrim teorisi dinamik insan ve evren anlayışıyla ${ }^{34}$ paraleldir. Onun dinamik insan ve evren görüşünde de sezgisel bilgiye verdiği değer ve hayatın amacı olarak zorunluluktan hürriyete doğru yükselen tekâmül telakkisinde de Bergson'un etkileri görülmektedir. İkbal'de insanın tekrar dirilmesinin onun manevî gelişimine bağlı olarak bir seçenek olarak değerlendirilmesinde de Bergson'un dinamik hayat felsefesi, özgürlük anlayışı ve şahsiyet kazanmanın önemini belirten görüşlerinin izleri vardır. Alışkanlıkların içerisinde otomat hale gelen insanla, şahsiyet kazanan insan arasındaki bu ayrım, Bergson'da görülmektedir ki ${ }^{35}$ bütün bu felsefi görüşler İkbal'in eserlerindeki en önemli yönlerini beslemektedir. Onun dinamik yaşam felsefesini desteklemesi açısından evrim teorisi imkânlarla doludur ve düşünür bu teoriyi özgürce yorumlamaktadır.

İkbal'de yaşam bir mücadele olarak görüldüğü için insanın başarı ve mutluluğu da bu hayat mücadelesindeki sertliğine bağlanmakta ve bu vurgu, değişik vesilelerle ve farklı bağlamlarla sürekli tekrar edilmektedir. Hayat bir kavgadır ve bu yaşam kavgasında başarılı olanlar bu kurallara riayet edenlerdir. Evrimsel sürecin ebedî hayat için de geçerli olan bir kanun ${ }^{36}$ olarak görülmesi ise bu teoriye metafizik bir anlam yüklemektedir. Ne bu hayatta ne ahiret hayatında bir yerde durup kalmamak, sürekli hareket ve tekâmül halinde olmak, onun en büyük tutkusudur: Gidersem varım; gitmezsem yokum!, "Cebrâil veya hûri seni bu yolda durdurmak ister, sakın bu yolda durma!" 38 Diyen şairdeki sürekli bir faaliyet ve arzu içinde olmak düşüncesi, evrimin temel felsefesiyle de uyuşmaktadır. İkbal'in hayat ve hareket arasındaki kurduğu bu ilişkinin arkasında Bergson'un hayatı hareketle eşit gören felsefesinin etkileri açıktı. ${ }^{39}$ Bergson'a göre insan düşünmek için değil, hareket etmek için var olduğundan dolayı düşünmesinin dahi nihai gayesi hareket etmektir. ${ }^{40}$ Elbette hareket, tekâmülle, tekâmül ise güç ve başarıyla neticelenecektir. ${ }^{41}$

İkbal'in tekâmül anlayışı onun sürekli yaratıcı faaliyet görüşüne göre şekillenmektedir. Geleceğin önceden belirlenen bir plana göre gerçekleşmediği ve imkânlara açık olduğu bu tekâmül anlayışında da İkbal, Bergson'dan etkilenmiş olmalıdır. ${ }^{42}$ Bergson'a göre hayat, sonsuza akmakta olan bir yaratma isteğidir. ${ }^{43} \mathrm{ikbal}$ açısından ise ölümden sonraki hayat, gerçekleşmemiş arzuların

göre önceden belirlenmiş bir plana bağlı olması açısından teleolojik olmasa da hayat amaçlı bir faaliyettir. Netice itibariyle hayat, Bergson'un iddia ettiği gibi düzensiz, amaçsız, keyfi ve tahmin edilemez değildir (Halife Abdülhakim, "Muhammed İkbal”, çev. Yusuf Ziya Cömert, İslâm Düşüncesi Tarihi, ed. M. M. Şerif - Mustafa Armağan (Istanbul: İnsan Yayınlar1, 1991), 4/406-407.

33 Abdülhakim, "Muhammed İkbal", 405-406.

34 Ahmet Albayrak, “ikkbal'de Dinamik İnsan Anlayışı”, Dîvân İlmî Araştırmalar Dergisi 5/2 (1998), 249.

35 Bk. Bergson, Yaratıcı Tekâmül, 1-52.

36 Muhammed ikkbal, Şarktan Haber (Zebûr-i Acem Peyam-ı Maşrık), çev. Ali Nihad Tarlan (İstanbul: Sufi Yayınları, 2006), 78, 79, 84, 91 .

37 İkbal, Şarktan Haber, 96.

38 ìkbal, Şarktan Haber, 216.

39 Bergson, Yaratıcı Tekâmül, 170-171, 322.

40 Bergson, Yaratıcı Tekâmül, 381.

41 Bergson, Yaratıcı Tekâmül, 171-179.

42 Bergson, Yaratıcı Tekâmül, 143.

43 Bergson, Yaratıcı Tekâmül, 324. 
ebedi olarak gerçekleşeceği bir yer değildir. Hayatın mükâfatı hayatın daha derin potansiyellerinin gerçekleştiği daha yüce bir hayattır. Bu bakış açısına göre acı dahi egonun gelişmesini sağladığından, nihai anlamda iyidir. Benlik, sürekli bir engellemeye karşı verdiği reaksiyona göre gelişmektedir. Acı çekmenin kaçınılmaz olduğu bu durumda bireyin ahlâkî ve ruhî gelişimi iç ve dış engellerle karşılaşmasına bağlanacaktır. Gerek şer ve gerekse şerrin en yüksek sembolik karakteri olan şeytan da bu bağlam içinde değerlendirildiğinde bir anlam kazanmaktadır. İnsanın gelişimi açısından büyük rolü olan şeytanın olmadığı bir hayat tasavvur edilemez. İnsanın cennetten düşüşü dahi bu görüş çerçevesinde te'vil edilmekte ve âdetâ insanın yükselişi bu düşüşe bağlanmaktadır. Buradaki düşüş ona göre insanın içgüdüleriyle var olduğu ilkel bir konumdan, şüpheye, itaatsizlik yeteneğine ve özgür bir benliğe sahip olduğu bir mertebeye yükseliştir. İnsanın cennetten düşüşü basit bilinç halinden, kendinin farkına varmasının ilk aşamasına geçmesine işaret eder. Artık insan için yeni cennet, daha fazla imkânlar barındırmaktadır. ${ }^{44}$

İkbal'in tekâmül anlayışı insanla hayvan arasındaki farkı bir derece farkı değil de bir mahiyet farkı gören Bergson'la aynıdır. ${ }^{45}$ Bergson'a göre insanın tabiat içerisinde ayrıcalıklı bir yeri vardır ve insanla hayvan arasındaki uçurum kapatılamayacak kadar büyüktür. Bergson'a göre de temelde bütün canlılar birbirine bağlıdır ve hepsi de hayat hamlesine boyun eğmektedirler. Bu hiyerarşik yapı içinde insanlar hayvanlara hayvanlar da nebatlara dayanmaktadır. ${ }^{46}$

Hak ve bâtılı dahi güce göre ayıran İkbal ${ }^{47}$, ezilmişsen yumuşak olduğundandır diyecek, kurtulmayı mücadeleyle pişmeğe bağlayacaktır. ${ }^{48}$ Âb-1 hayatın kılıcın keskinliğinde aranmasını öğütleyecektir. ${ }^{49}$ Fertlerin gelişmesinin bu acımasız savaşlara bağlanması, Bergson'un felsefesinde çok daha bârizdir. Bergson'a göre her türün sadece kendisini düşünmesi ve kendisi için yaşaması, tabiattaki bütün savaşların ve düzensizliklerin kaynağıdır. ${ }^{50} \mathrm{Fert-toplum} \mathrm{arasındaki}$ ilişki ağı da bu tekâmüle tabi olarak şekillenmektedir. Mikro âlemdeki topluluklardan insana varana kadar tekâmül süreci devam etmekte, insanların toplum haline gelmesiyle bir üst aşamaya geçmekte, tekâmül, fertten cemiyete, cemiyetten ferde akan hiyerarşik bir düzeni takip emektedir. Bu düzen, aynı zamanda birlik ve çokluk arasındaki ilişkiyi de gösteren bir tekâmül anlayışına göre şekillenmektedir. Birlik ve çoklukta aynı kanunun olduğu varsayılır ve buradaki birlik ve çokluk kavramları Bergson'a göre cansız maddenin kategorileridir, "hayat hamlesi”, ne saf birlik ne de saf çokluktur. Tekâmül süreci düşünceye doğru yol alırken, değişik aşamalardan geçmektedir. ${ }^{51}$

İkbal'in evrimci düşüncesini besleyen, etkilendiği önemli düşünürlerden birisi de Nietzsche'dir. Nietzsche'nin güç tutkusu İkbal'in düşünce evreninde derin izler bırakacak, ỉkbal, filozof kadar

44 Abdülhakim, "Muhammed İkbal”, 41-45.

45 Bergson'a göre tekâmül sürecinde zekâ, hayvandan insana ani sıçramayla sağlanmış ve hayatın bütün organikleşme ve tekâmül hikmeti insanda toplanmıştır (Bergson, Yaratıcı Tekâmül, 239-242).

46 Bergson, Yaratıcı Tekâmül, 345-348.

47 İkbal, Benlikve Toplum, 64.

48 İkbal, Benlikve Toplum, 71-72.

49 İkbal, Benlikve Toplum, 79

50 Bergson, Yaratıcı Tekâmül, 329.

51 Bergson, Yaratıcı Tekâmül, 334-337. 
bu konuda tutarlı olmasa da güçlülüğün aynı zamanda haklılık anlamına geleceği -her ne kadar sonraları bu düşünceye rezervler koysa da kanaatine varacaktır. Nietzsche'nin merhameti bir erdemsizlik sayıp, acımasızlığı onun yerine bir erdem olarak koyması, güçsüzlerin yok edilmesini, ezilmesini bir hak ve adalet görmesi, her şeyden önce bütün bunları Tanrı'nın olmamasına bağlamass, ${ }^{52}$ íkbal için oldukça uzak düşüncelerdir. Fakat yine de ìkbal, onun düşüncesinin cazibesinden kendini kurtaramamakta, zayıfların ezilmeye mahkûm olması, acıların insanı olgunlaştırıcı etkisinin olduğu, ${ }^{53}$ tarzındaki düşüncelere İkbal'de sıkça rastlamaktayız. İkbal, her şeyden önce dünyadaki acıların ve haksızlıkları modern bilimin evrim teorisiyle reddedilmeyecek şekilde ortaya koyduğu ve bunun da teizmin çözmekte zorlandığı kötülük problemini gözler önüne serdiği kanaatini taşımaktadır. ${ }^{54}$ üşünür, Nietzsche'nin teoloji ve ahlâk alanındaki düşüncelerine zemin hazırlayan evrimci görüşlerini sonuna kadar tutarlı olarak savunamayacaktır. Her şeyden önce İkbal, ahlâkın kaynağını doğada aramadığı gibi onun evrimciliği de Tanrı'nın varlığını dışlayacak bir mahiyette değildir.

Ülken'in belirttiği gibi Nietzsche'nin evrimciliği Darwinci anlamda biyolojik bir evrimcilik değil, metafiziksel boyutu olan evrimciliktir ve filozofa göre insanın kendini aşması bir zorunluluktur. ${ }^{55}$ İkbal, insanın kendini aşmak zorunda olduğuna dair Nietzsche'nin üstün insan felsefesiyle birlikte tasavvuftaki insan-1 kâmil felsefesinden, egonun gelişmesinin zorunluluğu çerçevesinde etkilenmiş olsa da her iki görüşe de belli rezervler koymaktadır. İkbal, Nietzsche'nin Tanrı'nın varlığını inkâr eden ve hiçbir ruhânî bağlllığı kabul etmeyen, gelişmek için merhameti günah sayan süper insanını (übermensch) ${ }^{56}$ onaylaması zaten düşünülemezdi. Dolayısıyla evrimsel düşünceden ve doğadan hareket ederek filozofun vardığı çıkarımlar, en son tahlilde i̇kbal'in metafizik evrim anlayışından farklı olacağı kaçınılmazdır. Bu anlamda İkbal, bütün etkilenmelere rağmen tutarlılı̆̆ını olmasa da orjinalliğini korumaktadır.

\section{2. İkbal'in Gözüyle Genel Çizgileriyle Evrim Teorisi}

İkbal daha 1904'te yazdığı "Millî Yaşam” adlı makalede evrim teorisi üzerinde uzunca duracaktır. Ona göre bu teori yaşamın sırlarını çözmesi, insan, hayvan ve bitki arasındaki evrensel savaşı ortaya koyması açısından oldukça heyecan veren bilimsel bir buluş ve bilim adamlarının uzunca uğraşlar sonucunda keşfettikleri evrensel bir yasadır. İnsanın gelişmişliğini bu yasa üzerinden ele alan İkbal, anlaşılan sadece biyolojik evrime değil sosyal evrime de inanmaktadır ve dünyada binlerce dinin doğup, gelişip sonra da yok olmasını bu evrimsel yasa ışığında değerlendirmektedir. Gelişen insan beynine cevap veremeyen dinler de ona göre bu yasa gereği yok olmaya mahkûm olmuştur. Yeni insana rehberlik edecek dinin gelişmesi ve insana ayak uydurması o dinin hayatiyeti için şarttır. Sadece dinler değil, dillerin ölümleri dahi yine bu yasayla açıklanmaktadır. Daha üstün bir medeniyet karşısında daha az gelişmiş̧ ilkel medeniyetler de yok olmaya

52 Friedrich Nietzsche, Güç İstenci. çev. Sedat Umran (İstanbul: Birey Yayıncılık, 2002), 47.

53 Nietzsche, Güç İstenci, 50-52. İkbal, belayı adetâ rahmet olarak görmektedir. "Ben o yolcunun müridiyim ki o, dağı, çölü ve denizi olmayan bir çöle ayak basmanıştır." İkbal, Câvidnâme, 295; "Yarasız yaşamak, yaşamamaktır; ayağın altında ateş bulunurken yaşamak lâzımdır". İkbal, Câvidnâme, 300.

54 İkbal, İslâm'da Dinî Düşüncenin Yeniden İnşası, 114-115.

55 Hilmi Ziya Ülken, Yeni Zamanlar Felsefesi, 2. Basım (İstanbul: İş Bankası Yayınları, 2016), 111.

56 İkbal, Câvidnâme, 35. 
mahkûmdur. Bu yaşam savaşında -ki gelişmek için bu savaş kaçınılmazdır- insanlığın gelişimi için uluslar, ulusların gelişimi için de bireyler yok olacak ve bireylerin hakları ihmal edilecektir. Peygamberler, akıl ve mantığa değil, sıradan insanın gücünü aşan ruhanî ve sıra dışı güçlere dayanmakta ve bir din bunlarla hayat bulmaktadır. Din, kültür ve medeniyetin bir meyvesi olarak insanlığın gelişimindeki katkılarıyla ele alınmaktadır. Köleliğin kaldırılması dahi insanın gelişimine paralel olarak insanın özgürleşmesinin zorunlu bir sonucudur ve bu da ona göre din eliyle olmuştur -ìkbal İslâm'ın köleliği kaldırdığı ve insanlar arasında eşitliği getirdiğini düşünmektedir-. İnsanın gelişimi ve özgürlüğü bağlamında içtihat yapılmasını savunmaktadır. ${ }^{57}$

İnsanın biyolojik evrimi gibi toplum ve bireyin de evrimi vardır. Biyolojik realitenin çok ötesinde olan evrim, yaratıc faaliyetin zevkinin tezahür etmesidir. Hayat sürekli ileriye doğru bir hamledir. Ona göre Kur'ân da evrim fikrine düşman değildir. Evrim teorisini evrensel bir yasa olarak gören düşünür, bu teorinin dinle çatışmasının imkânsız olduğunu ihsas ettirmektedir. Doğa yasasının Kur'ân tarafından reddedilemeyeceği dolayısıyla din-bilim çatışmasının olamayacağı düşüncesi İkbal'in yaşadığı coğrafyadaki bazı Müslüman düşünürlerce hararetle savunulmaktadır. ${ }^{58}$ Evrim teorisindeki dinamik yapıdan İkbal, her konu açısından yeni imkânlar bulmaktadır. Kelâm ve fikıh gibi ilimlerin yenilenmesinin gerektiği düşüncesi de evrim teorisiyle daha doğrusu dinamik bir yaşam felsefesiyle temellendirilmektedir. ${ }^{59}$ İkbal kadın konusunu da evrim teorisi bağlamında ele alacaktır. ${ }^{60}$

İkbâl'in 1910 tarihinde kaleme aldığı "İslâm Milleti Hakkında Sosyolojik Bir İnceleme" isimli makalede evrim teorisi paralelinde sosyolojik tahliller yapılmaktadır. Ona göre doğanın ertelenemez olan kanunları, insanın amaç ve hedeflerini umursamadan kendine mahsus hedefleri gerçekleştirmektedir. Çevre şartlarının belirleyici olduğu bu doğal ortamda insan diğer hayvanlara nazaran çok daha zayıftır. ${ }^{61} \mathrm{ikbal}$, insanlığın en büyük bilimsel keşiflerinden gördüğü “doğal seçilim ilkesi”nin insan neslinin tarihsel gelişiminin rasyonel açılamasını yaptığını düşünmektedir. Ona göre insanlık tarihini anlamamızda büyük bir kolaylık sağlayan bu kanun, derinlemesine incelendiğinde sadece biyolojik değil, medeni hayatın sosyolojik, siyasî, ahlâkî ve ekonomik yönden anlaşılmasının da önünü açacaktır. Bireyin toplum içindeki rolü daha doğrusu iradesizliği, toplum tarafından kuşatılmışlı̆̆ı ve toplumun varlığını sürdürmesinin gerekliliği açısından fert-toplum ilişkisi gibi durumlar da bu teori çerçevesinde ele alınmaktadır. ${ }^{62}$

Evrim teorisi, İkbal'in elinde dinin lehine kullanılacak bir silaha dönüşmektedir. Özellikle Mevlânâ'nın şiirleri üzerinden evrim teorisinde gördüğü imkânlar, onun meseleye aklî ve bilimsel kanıtlardan çok, mistik bir heyecanla bakmakta olduğunu göstermektedir. Dolayısıyla íkbal'in bilimsel olarak bu kanıtı etraflıca tartışmak gibi bir niyeti yok gibidir. Ona göre hep ileriye doğru bir hamle olan hayatın içinde varoluşun coşkusu, Tanrı dâhil her varlığı kuşatmıştır. İnsanın özgürlüğü dahi bu teoride anlamını bulur. İkbal, yaratılışta sahnelenen bir senaryonun kesinliği

57 Muhammed İkbal, “Milli Yaşam”, Makaleler, çev. Celal Soydan (Ankara: Hece Yayınları, 2017), 21-32.

58 Bk. Mustafa Öztürk, “Çağdaşlık ve Çağdaş Dönem Kur’an Yorumlarına Genel Bir Bakış”, İslâmiyât 7/4 (Ekim-Aralık 2004), 71-94.

59 İkbal, İslâm'da Dinî Düşüncenin Yeniden İnşası, 204-205.

60 İkbâl, Makaleler, 32-37.

61 İkbâl, Makaleler, 75.

62 İkbâl, Makaleler, 76-94. 
ve sıkıcıllğını değil, imkânların çokluğunu ve nisbi bir belirsizliğini görür. ${ }^{63}$ Onun din yorumlaması da bu paraleldedir, dinamik bir din anlayışının temelinde hem evrim teorisinin imkânları hem de vitalist düşüncenin etkileri vardır. Filozof-şair, Allah'la insan arasında hayat dolu bir gerginliğin, tatlı ve heybetli konuşmanın yerini, asırlar içinde donuklaşan şekilciliğin hâkim olmasının rahatsızlığını taşır. Sadece şekilcilik değil, yanlış mistik telakkiler de onun eleştirilerinin hedefindedir. Bundan dolayı insanın kişiliğini Tanrı'da eritmeği amaçlayan mistik anlayışları da tenkit etmektedir. ${ }^{64}$ íkbal'in dinamik ego felsefesi mutlak ben olan Tanrı'yı da kapsamaktadır. Tanrı, statik, değişmeyen geleneksel Tanrı tasavvurlarının dışında yeni bir tasavvurla ele alınmaktadır. Tanrı-âlem ilişkisinin yeni bir şekilde anlaşıldığı bu süreç felsefesinde İkbal, Batı felsefesiyle henüz irtibat kurmadan önce dahi "zaman" ve "değişme" kavramları üzerinde yoğunlaşmışsa da bu düşüncelerin gelişip olgunlaşmasında modern dönemde Bergson, Whitehead (1861-1947), James Word gibi düşünürlerin yanında ${ }^{65}$ kadim İslâm düşüncesinden de özellikle Sadreddin Konevî ve İbn Arabî’den etkilenmektedir. ${ }^{66}$ Özellikle İbn Arabî̀nin ilahi varlı̆̆1 lâhut ve nâsut yönleriyle ele alması İkbal'i etkilemiş olmalıdır. ${ }^{67}$ Bitmemiş âlem ve Tanrı anlayışının temellerinin Kur'an'a dayandığı konusundan ısrarcı olan İkbal, bu tasavvurun Yunan düşünürlerinin etkisinde kalan Müslüman düşünürler tarafından terkedildiğini iddia etmektedir. ${ }^{68}$

İkbal, âlemi bir masiva olarak Tanrı'nın karşısına konulmasını eleştirmekte ve âlemin bağımsız bir gerçeklik olduğunu kabul etmemektedir. Mekân, zaman ve madde ona göre Tanrı'nın özgür yaratıcı enerjisine giydirilen yorumlardan başka bir şey değildir. Panteist ve mistik bir Tanrı tasavvurunun sınırlarında dolaşan düşünüre göre, sürekli ilahi fiil olan madde dünyass ${ }^{69}$ Nihâî Ego olan Tanrı'yla organik bir bütünlük içindedir.Değişimin yaratıcı faaliyetle gerçekleştiğini düşünen İkbal Tanrı'nın karşısında "öteki” diye tanımlayacağımız bir âlemin olmadı̆̆ı kanaatindedir. ${ }^{70} \mathrm{En}$ büyük ego olan Tanrı gibi diğer egoların hepsi de gerçektirler, onların varlığı Tanrı'nın muhayyelesinde değil, gerçek şahsiyetler olarak Tanrı'nın varlı̆̆ındadırlar. ${ }^{71}$ İlahi varlığın yanında diğer varlıkların da şahsiyet sahibi hakiki varlıklar olduğunu varsayması, i̇kbal'i vahdet-i vücudçu Tanrı tasavvurundan da panteist Tanrı tasavvurundan da uzaklaştırdığı gibi, âlemi Tanrı'nın karşısında konulan gerçek bir varlık olarak görmemesi onu kelâmcıların Tanrı tasavvurundan da uzaklaştıracaktır. Bütün bu egolar gelişmek ve bir üst egoya çıkmak için sürekli bir mücadele içindedirler, bu daimî mücadelenin bir sonu olmadığı gibi en büyük ego olan Tanrı'ya ulaşıp onun varlığında eriyerek yok olmak gibi bir amaçları da yoktur. İkbal, gelişmiş bir ego olan

63 Tekâmül sürecindeki imkânların rolüne Bergson da dikkat çekmektedir (Bergson, Yaratıcı Tekâmül, 329).

64 İkbal, gençlik dönemi eseri olan doktora tezinde bile dünyadan el etek çeken tasavvufî anlayışların Kur'an'ın ruhuna aykırı olduğunu söyleyecektir ( İkbal, İslâm Felsefesine Bir Katkı, 101).

65 Mehmet S. Aydın, "Süreç (Proses) Felsefesinin Işı̆̆ında Tanrı-Âlem İlişkisi”, Ankara Üniversitesi İlahiyat Fakültesi Dergisi 27/1 (Ağustos 1986), 39-40.

66 Aydın, "Süreç (Proses) Felsefesinin Işığında", 62.

67 Aydın, "Süreç (Proses) Felsefesinin Işı̆̆ında", 60-62.

68 Aydın, "Süreç (Proses) Felsefesinin Işı̆̆ında”, 40.

69 İkbal, İslâm'da Dinî Düşüncenin Yeniden İnşası, 98.

70 İkbal, İslâm'da Dinî Düşüncenin Yeniden İnşası, 110-111.

71 İkbal, Câvidnâme, 27-28. 
insanda Tanrı'nın iradesini değiştirecek bir güç olduğu kanaatindedir. ${ }^{72}$ Değişim Tanrı'nın yaratıcı faaliyetinin kaçınılmaz bir sonucudur. Aksini düşünmek ona göre Tanrı'yı fiilsiz donuk bir şekilde tasavvur etmek demektir. Yalnız bu değişim Mutlak Egoya mahsus olan saf zaman içinde olan sürekli yaratma anlamında bir değişimdir. Tanrı'daki değişim, tavırların, hallerin peş peşe geldiği sıralı bir zaman içinde meydana gelen bir değişim olmadığı gibi, O'nun hareketi dahi eksiklikten mükemmelliğe doğru bir hareket değildir. ${ }^{73}$ Böylece İkbal, en büyük ego olan Tanrı'nın evrimsel düşünceye paralel olacak şekilde hareketten ve değişimden müstağni olmadığını düşünmekte, hem de saf zaman-ardışık zaman tasnifine uygun olarak bu değişimin Tanrı'da çeşitlilik, hâller ve tavırlar olarak ardışı bir zaman içinde olmadığını söyleyerek Tanrı'da eksikliği çağrıştıracak böyle bir tasvirden kaçınmış olmaktadır. Bu bağlamda Aristo'nun hareket etmeyen Tanrı tasavvuru, İkbal'in Tanrı tasavvuruna yabancıdır. Yaratıcı kudret bütün varlığın dışarıdan bir seyircisi değil, yaratma faaliyetinin daimî faili, insana özgürlük vererek bir risk alacak ve insana güvenecek $\mathrm{kadar}^{74}$ bu varlık coşkusunun bir tarafıdır. Hayatın coşkusu evrim teorisine uygun olacak şekilde egolar arasındaki çatışmalardan ve hayatta kalma hamlelerindeki seçimlerden doğmaktadır ki insanın özgürlüğü aynı zamanda onun diğer egolara olan üstün yönlerinden birisidir. İkbal'e göre Tanrı bu anlamda değişim halinde olan bir varlıktır. İkbal, İslâm filozoflarının, kelâmcıların ve sûfilerin Tanrı tasavvurlarını eleştirmektedir. Tasavvufçuları eleştirmek adına tarihten seçtiği en önemli figür ise Hâfız-1 Şîrâzîdir (ö. 792/1390 [?]) I5 İnsan şahsiyetini Tanrı'nın egosunda yok etmeyi bir erdem olarak gören bu mistik düşünce, íkbal'in sert eleştirilerinin hedefi olacaktır. Zira ona göre ego gittikçe güçlenen şahsiyeti merkeze alan ve gelişmek için savaşan bir yapıya sahiptir. Ego sadece Tanrıda değil, atomdan insana bütün varlıklarda bulunmaktadır ve bu egolar da Tanrı'nın iradesiyle varlıklarını sürdürmektedirler. En büyük ego olan Tanrı, diğer egoları yok etmeyi istememektedir. Her egonun kendisinden daha yüksek bir ego haline gelmeyi amaçlaması ise bitmeyen bir mücadeleyi zorunlu kılacaktır. İnsanın içinde sonsuz imkânlar gizlidir. Evrim teorisi onda insanın ebediliği ve egosunun gelişimi için de önemli bir zemindir. Bilimsel evrimden metafizik imkânlar çıkarmakta, dünya hayatını sonsuz hayat için bir önsöz mesabesinde görmektedir. Her ego ferdileşmeye yatkındır. Artık o her varlığın kendine ait organları geliştirmeğe çalışması düşüncesiyle Lamarck'ın düşüncesine katılmaktadır. İkbal'e göre yerin göğün kabul etmediği ve insana yüklenen ilahi emanet, iyi-kötü bütün imkânlarıyla şahsiyettir. İnsan en mükemmel ego olan Allah'ın şahsiyetine mümkün olduğu kadar yaklaşması gerekir. “İnsanın Allah'ın ahlâkıyla tahalluk etmesi”ni İkbal, insanın Allah'a benzemeye çalışması olarak yorumlayacaktır. İnsandaki arzu cennette dahi devam etmekte, insan sürekli bir savaş-zafer-savaş döngüsü içerisinde varlığını sürdürmektedir. Bu noktada şeytanın ve şerrin varlığı dahi bu savaşın ve insanın gelişiminin kaçınılmaz unsurları olarak onun felsefesinde müspet bir değer kazanıyor. Bu anlamda Âdem ve Havva'nın cennetten çıkması güzel bir gelişme olduğu gibi İblis de burada oynadığı rolle yaşamın coşkusuna katkı da bulunan önemli bir aktördür. Bütün bunlardan sonra egonun bazı mistiklerin idealize ettiği gibi yok edilmesi değil, güçlendirilmesi gerekir. İkbal, tasavvuftaki yolculuk kavramını da buna uygun yorumlayacak ve

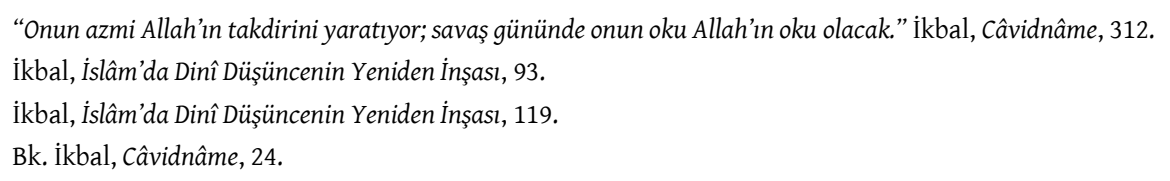


insanın evrimsel sürecini sürekli olan bir yolculuğa benzetecektir. Yürürsem varım, yürümezsem yokum diyen İkbal, bu yolculuğun sonsuzluğuna inanmaktadır. İnsanın bu yolculuğu sadece bu dünyayla sınırlı değildir. İnsanın ahiretteki hayatı da ulûhiyetin derinlerinde bitmeyecek bir yolculuktur. Her sonu yeni bir başlangıç takip edecek, her veda yeni bir yolculuk sürecinin şartı olacak ve bundan yaşamın sonsuz coşkusu doğacaktır. ${ }^{76}$ Hayat sürekli bir inkılaptır, bütün varlık hareket halindedir, yolcu gibi yol da yürümektedir ve bu heyecan evrendeki her zerrede bulunmaktadır. Hayat kervanı sürekli yoldadır ve her varlıkta bir göçme telaşı vardır. Ölüm ve hayat iç içedir. Bir gül bahçesi dahi ölmekte olan ve gonca olarak hayata gelen güllerle bu hakikatin göstergeleridir. Bu daimi yürüyüşte hayat, ölüme yabancı değildir. Hür insan için ölüm dahi yeni bir hayattır. ${ }^{77}$ Kemikleşmiş gelenekler, insanın yolundan alıkoyan engeller olarak görüldüğünden, bunlara isyan etmek dahi insanın egosunu güçlendirmesi ve faaliyetini devam ettirmesi için gereklidir. Bu yolda taklit etmek, egonun gelişimini engelleyen bir unsur olarak eleştirilmekte ve içtihat kapısının kapatılmasının öldürücü özelliğine dikkat çekilmektedir. ${ }^{78}$ Tohumun inkişaf etmesi gibi insanın da büyüyüp gelişmesi imkânlarının ortaya çıkması yaşamın amacı ve zevkidir. İnsanın yapması gereken manevi miracın dahi bu evrim teorisiyle ilişkisi kurulabilir. ${ }^{79}$ İnsan, ölümle dahi sonlanmayan bir gelişim süreci içerisindedir. Hareket, değişim, insanın halden hale geçmesi ve bir noktada kalmaması idealize edilmektedir. Yaşadığı dönem açısından İslâm dünyasının geri kalmışlı̆̆ı Batı'nın gelişmişliği ve çalışkanlığı da evrim teorisinin hayattaki akisleri olarak şairin dünyasında karşıllk bulacak ve bu bağlamda maddî ve manevî her türlü başarı yüceltilecektir. Sadece bir mücadele alanı olan hayattan zaferle çıkanlar yaşama hakkına sahip olabileceklerdir. Başarının ve gücün yüceltilmesiyle; çalışmak, erdem, dilencilik ve insanlardan bir şey istemek ise zillet sayılacaktır. İkbal, evrimci yaratılış teorisine uygun olacak şekilde fakirliği bir erdem olarak gösterecek her türlü imadan kaçınmakta, gücü ve başarıyı yüceltmektedir. İkbal bu tekâmül anlayışını güçlendirmek adına tasavvufî kavramları da seferber etmektedir. Mesela egoyu güçlendiren aşk kavramı dinamik insan anlayışının itici gücü olarak görülmekte ve bu anlamıyla aşk yaratıcı hamle (elan vital) olarak anlaşılmaktadır. Aşk bütün sınırları aşan sevgi değil, arayana hasret veren hayatın en önemli unsurudur. ${ }^{80} \mathrm{I} k b a l$ 'in tasavvufi bir kavram olan "fakr" kelimesine yüklediği anlam dahi güçle ilişkilidir. Buradaki "fakr" kelimesi acziyete ve muhtaçlığa değil, insanın bütün ihtiyaçlardan müstağni olan gücüne işaret

76 Bk. İkbal, Câvidnâme, 31-51.

77 Bahaîliğin ölümden sonra ruhî tekâmülün devam edeceği ve insanın Allah'a yolculuğunun ölümle birlikte başlayacağına dair görüşüyle (Ethem Ruhi Fığlalı, Bâbîlik ve Bahâilik (Ankara: Türkiye Diyanet Vakfı Yayınları 1994), 66-67) paralellik arz etmektedir. İkbal'in cennet ve cehennem anlayışı da Bahailiğin görüşleriyle benzerlik göstermektedir. İkbal düşüncesinde aşk yolculuğunda menzile ulaşmaktansa yolculuk halinde olmak daha iyidir demektedir (ìkbal, Hareket Zili, 133).

78 İkbal, Câvidnâme, 410-432. İkbal, taklide karşı duran bu anlayışıyla uyuşmayacak şekilde yeni içtihatlara müsaade etmeyecek ve zor zamanlarda şeriatın teferruatlarına sarılmanın Müslüman toplumun kimliğini koruyacak bir hareket olduğunu söyleyecektir (Muhammed İkbal, Mektuplar, çev. Halil Toker (İstanbul: Kaknüs Yayınları, 2002), 77-78.

79 İkbal, Câvidnâme, 104-105.

80 Schimmel, Muhammed İkbal, 75; Mesela aşkın karşısına ilmi koyarak, aşkı, Hz. Peygamberle; ilmi Ebû Leheb’le özdeşleştirecektir. Bu mistik coşkuyla yine aklı bilimle; aşkı, Âdemle özdeşleştiren üstadı Mevlânâ’ya katılacaktır. Aşksız ve dinden uzak ilmi şer olarak görmektedir (i̇kbal, Câvidnâme, 220-221). İkbal'in düşünce dünyasında tasavvufî ıstılahların nasıl konumlandığını ele alan bir çalışma için bkz. İsa Çelik, Muhammed İkbal'in Tasavvufi Düşüncesi (İstanbul: Kaknüs Yayınlar1, 2004), 203-279. 
etmektedir. Böyle bir durum başlı başına bir zenginlik ve ruhsal bir güçtür. İkbal'in düşünce sisteminde dilencilik ruhu zayıflatan en temel eylemlerden biri olmasına ${ }^{81}$ karşın tasavvufî anlamdaki "fakr", egoyu güçlendiren, insanı krallardan bile yüce yapan ${ }^{82}$ bir erdemdir.

İkbal, yaşam savaşını, güç mücadelesinin coşkunluğu ve hayatın dinamik süreci olarak görmektedir. Ona göre ilahi kudret, mücadelede bir lezzet buluyor, gücünü deniyor ve bu güçle öldürüyor. Bir gül için yüz gülistanın kanını döküyor; bir felek için yüz hilal, bir söz için yüz laf yaratıyor. Bütün bu israf, manevi güzelliği tamamlamak içindir. Gül gibi kandan abdest almak hayatın ta kendisidir. ${ }^{83}$ İnsan, arzusuyla bir mezara dönmekten kurtulacaktır. ${ }^{84}$ Onun şairane üslubuyla evrim teorisinin acımasız ilkeleri estetize edilmekte, bu çetin yaşam savaşında bir güzellik aranmaktadır. Keklik cilveli yürüdüğü için güzel bir ayağa; bülbül, nağme peşinden koştuğundan gagaya sahip olmuştur, hayatın sermayesi ise arzudur. ${ }^{85}$ İnsanı yaşatan bir güç olarak arzu, İkbal'in düşüncesinde pozitif bir anlam kazanır. İnsanın arzularıyla mücadele ederek nefsini öldürmeye çalışmasını telkin eden ahlâk anlayışları ve mistik telakkiler ona göre insanı pasifleştirmekte, statik ve dingin bir hayata sürüklemektedir. Onun değer anlayışında dinginlik ölüm; devamlı bir mücadele etmek ve büyüme arzusunu taşımak ise hayat ve erdemdir.

Kur'ân'daki Âdem'in yaratılış hikâyesi, cennetteki varlığı ve oradan düşmesi evrim teorisiyle uzlaşacak şekilde te'vil edilecektir. İnsan, Allah'ın iradesiyle yeryüzünde yaratılmış ve yine Onun iradesiyle insan dâhil olmak üzere sonlu egolar sonsuz bir varoluşla varlık sahasına çıkmışlardır. Hayat, en düşük seviyedeki ego olan maddeden, maddenin ilk tezahürü olan tek hücreli organizmalardan insan düzeyine ulaşana kadar tedricî bir yükselişi içerisindedir. Madde nihai ego olan Tanrı'nın kendini açıklamak üzere ortaya koyduğu "ben-olmayan"dır. Nihai egodan ortaya çıkan madde, düşük seviyede olsa da, varlık hiyerarşisinin fizik seviyedeki aşaması olduğundan ölü ve hareketsiz değildir, Maddenin nihai egoyla olan ilişkisi kıvılcımın ateşle, damlanın okyanusla olan ilişkisi gibidir. İlahi egonun içkin olduğu madde aynı zamanda gerçekliğin haricî ifadesidir. İlahî rehberlikle daha yüksek seviyelere çıkan maddenin tedrici yolculuğu doruk noktasına insanda ulaşmaktadır. Maddenin evrimsel sürece tabi olan bu yolculuğu sürdükçe

81 İkbal'de benliği güçlendiren erdemler konusunda bkz. Mehmet S. Aydın "Muhammed İkbal'in Felsefesinde İnsan" Ankara Üniversitesi İlahiyat Fakültesi Dergisi 29/1 (1987), 95 vd.

82 “Fakr reisleri reisi, sultanların sultanıdır/ İlim hekim ve fakihtir, fakr ise Musa ve İsa'dır/ilim, yolu arıyor, fakr ise yolu biliyor/ Oysa istemek insanın manevi gelişimini de engeller. Ey lâhuti kuş, senin uçuşuna mâni olan ekmeğe ölümü tercih etmek daha iyi olurdu/ Ey bu eski evi terk etmekten bahseden, bu eski evi terk edeyim deme, onu teshir etmekten bahset!" Burada erdem olarak görülen fakirlik, insanı faaliyete sürükleyen fakirliktir, yoksa onu tembelleştiren ve muhtaç hale düşüren fakirlik değildir (ìkbal, Câvidnâme, 112-115).

83 Muhammed i̇kbal, Esrar ve Rumuz, haz. Ali Nihad Tarlan (İstanbul: Sufi Kitap, 2005), 33.

84 İkbal, daha önceleri anlaşılan Budist felsefeden etkisiyle arzulardan kurtulmayı idealleştirmekte ve isteklerden kurtulma isteğini dahi bir istek olması yüzünden insan için bir tuzak görmektedir (ìkbal, Hareket Zili, 85). İkbal, ilk dönem şiirlerindeki bu tarz düşüncelerini daha sonraları tamamen revize edecektir. Mesela, amelsizliği övdüğü, hem dünyayı hem de ahireti terk etmenin erdeminden bahsettiği, vahdet-i vücud düşüncesinin sembol ismi olan Hallâc-1 Mansûr'u idealize ettiği ve acıların kaynă̆ı olarak gördüğü arzulardan arınmayı öğütlediği, taklit etmenin erdeminden bahsettiği ( İkbal, Hareket Zili, 89-90) düşüncelerinin sonraları tamamen aksini savunacaktır ki bunda bize göre evrim teorisinin rolü büyüktür. 
karmaşıklığa paralel olarak varlığın önemi de artmakta zihin ve bilinç düzeyler ortaya çıkmaktadır. ${ }^{86}$

Evrim teorisi, ateist düşünceye bilimsel bir zemin olarak kullanılsa da İkbal gibi süreç felsefecileri olan teistleri oldukça heyecanlandırmıştır. Onlara göre Tanrı'nın iradesi doğrultusunda ilerlemeyi ve gelişmeyi esas alan bu teori, ${ }^{87}$ gelişmeye açık bir insan ve evren anlayışı ve Tanrı'nın özellikle insana verdiği irade yüzünden risk aldığı düşüncesine bilimsel bir katkı sağlamıştır. Evrimi kabul eden Hegel (1770-1831), ve Schelling (1775 1854) gibi düşünürler, Tanrı'nın varlığını açıklamada da bu kuramı kullanmışlardır. Schelling'in doğa felsefesinde cansızdan bitkiye; ondan hayvana ve sonunda insan zihnine ulaşan doğa, bu aşmalarda kendini gerçekleştirir; bu süreç de ancak Tanrı ile anlaşılabilir. Aslında burada Tanrı da evrenle birdir ve evrilmekte olan Tanrı'nın kendisidir. Hegel de insanlık tarihini evrimsel süreçle açıklamış, evrimi gerçekleştiren mutlak'ın-Tanrı- tinakıl- doğası insanın doğasıyla aynı görmüş, evrene içkin olan Tanrı'nın tarihin evrimsel sürecinde kendini gerçekleştirdiğini iddia etmiştir. ${ }^{88}$

\section{3. İkbal'in Evrim Teorisi Bağlamında Mistik ve Felsefi Düşüncelere Yönelik Eleştirileri}

Hayatı sadece güçlülerin ayakta kalacağı bir savaş alanı olarak gören İkbâl vahdet-i vücûdçu tasavvuf felsefesini, İslâm toplumlarının en önemli çöküş nedeni olarak hedefe koymaktadır. Onun nazarında bu tasavvuf felsefesi ve Yunan düşüncesi, insanı pasifize eden iki zehirli düşünceden başka bir şey değildir. Bu mistik yaşam felsefesi toplumsal çöküşün hem nedeni hem de sonucudur. Toplumu eylemden soğutan bu düşünce, aynı zamanda toplumun çöküş zamanında da sığınılacak bir liman olarak görülmekte, bir toplumun çöküşü bu tarz düşüncenin yükseliş zamanına tekabül etmektedir. Artık insanların yaşama azmi yok olmuş ve mücadele etme cesaretleri kırılmıştır. İnsanların umutlarını kıran bu mistik hava, toplum içindeki güçlü bireyleri dahi zamanla zayıflatacaktır. İkbal'e göre hiçbir hakikat ışığı olmayan ve toplum için kesinlikle zararlı olan bu düşünce, bir "palavra"dan ibarettir. ${ }^{89}$

Vahdet-i vücûd felsefesi, sadece benlik düşüncesi açısından tehlikeli bulunmamaktadır. İkbal'e göre bu düşünce sistemi, şiir yoluyla halka kadar sirâyet ederek Müslüman toplumları amel tutkusundan mahrum bırakmıştır. Ona göre bu düşünceye en önemli tepki gösterenlerin başında İbn Teymiyye (ö. 622/1225) gelmektedir. Bu düşünce sahipleri hareketsizliği bir erdem olarak pazarlayarak insanlardan eylem arzusunu yok etmişlerdir. ${ }^{90}$ íkbal, Vahdet-i vücûd felsefesini eleştirmek adına meşreben uzak olduğu İbn Teymiyye'ye atıfta bulunmakla ve sûfîleri insanları ifsada sürükleme ithamıla yetinmez ve eleştirinin dozunu daha da artırır. "Benliğin Gizlerinin Gizleri" isimli makalesinde bir zamanlar kabul edip sonraları yaşama hizmet etmediğini düşündüğü bu görüşü "zındıklık" sayacak ve bu görüşten tövbe ederek tekrar Müslüman

86 Jamila Khatoon, İkbal'in Felsefe Sisteminde Tanrı İnsan ve Kâinat, çev. Celal Türer (İstanbul: Üniversite Kitabevi Yayınları, 1963), 129-132.

87 Taslaman, Evrim Teorisi, 76.

88 Taslaman, Evrim Teorisi, 76.

89 İkbal, "İslâm ve Tasavvuf", Makaleler, 191-192.

90 İkbâl, "Benliğin Gizleri”, Makaleler, 105-108. 
olduğunu ${ }^{91}$ söyleyecek, mistik bir şair-düşünür yine farklı bir mistik telakkiyi zındıkça görecek kadar ağır ithamlarda bulunmaktan çekinmeyecektir.

İkbal'e göre Vahdet-i vücudçu tekâmül anlayışında varsayıldığı gibi "gelişmek ve üst bir aşamaya çıkmak mücadelesi veren egoların asıllarına dönmek" gibi bir amaçları yoktur. Egonun güçlenerek sürekli bir üst aşamaya çıkmasının bir sonu olmadığı gibi şahsiyet de hiçbir şekilde kaybolmayacak, insanın bu sonsuz yolculuğu cennette dahi devam edecektir. İkbal'in ferdî ruhun manevî gelişiminin nihâyetsizliği ve bu sürecin cennette dahi devam ettiği görüşü onun doktora tezinde incelediği Sühreverdînin İşrâk Felsefesi adlı eserindeki ferdi ruhun tekâmülüne dair görüşlerinden ${ }^{92}$ esinlenmiş olmalıdır. Dolayısıyla hayatın bitmeyen bir yolculuk olduğu düşüncesi, anlaşllan o zamanlarda dahi İkbal'in oldukça ilgisini çekmiştir. İkbal, “Sühreverdî’nin İranlı ilk sistematik düşünür ve bedeli kanla ödenen bir felsefenin kurucusu olan büyük şehid olduğunu" hayranlık ve heyecan dolu tasvirlerle anlatmaktan kendini alamaz. ${ }^{93}$ Anlaşlan Sühreverdî etkisi, düşünürün sonraki dönemlerinde de devam edecektir. Onun duygu ve aklı birleștirme hamlesi, ferdi ruh anlayışı, bitmeyen manevî yolculuk tasavvuru, íkbal düşüncesinde derin izler bırakmıştır. ${ }^{94}$

İkbal, bu tekâmülcü, şahsiyet sahibi, dinamik ego görüşü adına sadece tarihsel simalarla değil, yerleşik tasavvufi kavramlarla, dünyaya sırtını dönen züht anlayışılla, şahsi olmayan Tanrı tasavvuruyla da mücadele etmek zorunda kalacaktır. Ona göre insanları tembelliğe ve zayıflığa sürükleyen bu mistik anlayışlar, her şeyden önce Kur'an'la bağdaşmamaktadır. ${ }^{95}$ İkbal daha 1910 yılındaki bir not defterinde "gücün hakikatten daha ilahî olduğu" notunu düşse de daha sonraları bu görüşü biraz yumuşatarak "gücün hiç olmazsa hakikatle eşit olduğunu" söylemek gereğini duyacaktır. Onun iktidara olan arzusu bütün eserlerine hâkim bir düşüncedir. ${ }^{96}$ İnsan gibi kâinatın da tekâmül halinde ${ }^{97}$ olduğu düşüncesinde olan İkbal, evrenin dinamik yapısına işaret etmekte, mükemmelliğin statik bir yapıyı gerektireceğinden dolayı evrenin mükemmel olmadığını ima etmektedir.

İnsanın acılardan kurtulmasını arzularından kurtulmasına bağlayan Budist felsefeye karşı İkbal, arzunun da şahsiyetin de korunmasını savunmaktadır. ${ }^{98}$ íkbal'in düşüncesinde arzuların acılara yol açması, arzulardan kurtulmanın gerekçesi olamaz. Çünkü acı, insanın kaçınması gereken bir şey değildir. Sürekli arzu, sürekli mücadeleyi ve hareketi getirerek ferdiyetin gelişmesini sağlamaktadır. Egonun gelişmesi onun acı çekmesine daha doğrusu acıyla olgunlaşmasına; ferdiyetin gelişimi, insanın hayat denen savaş arenasında göstereceği performansa bağlıdır. Hayatın amacı ve zevki ilerlemek ve harekette bulunmaktır. Kendi gelişimi için gerekli

\footnotetext{
91 İkbâl, "Benliğin Gizlerinin Gizleri”, Makaleler, 118.

92 İkbal, İslâm Felsefesine Bir Katkı, 131.

93 İkbal, İslâm Felsefesine Bir Katkı, 129-132

94 Abdülkerîm el-Cîlı̂yi (ö. 832/1428) tanımlarken kullandı̆̆ı “şairane bir muhayyile ile felsefi bir dehayı birleştirerek mistik ve metafizik düşüncelerini şiir formuyla ifade etmeyi tercih etmesi” ( İkbal, İslâm Felsefesine Bir Katkı, 133.) ifadeleriyle şair, âdetâ kendi ideal kimliğini tasvir etmekte, olmak istediği insanın prototipini vermektedir. schimmel, Muhammed İkbal, 35-36.

Schimmel, Muhammed İkbal, 61.

Schimmel, Muhammed Ikbal, 74.

Aydın, “ikbal'in Felsefesinde İnsan”, 88.
} 
olduğundan dolayı insan, belaları dahi bir nimet bilmeli ve beladan korkmamalıdır. Gelişmenin ve büyümenin bir sonunun olmadığı bu hayat felsefesinde insana tavsiye edilen de her daim kervanda ve yolda olmasıdır. ${ }^{99}$ İkbal, görünen âlemin gerçekliğinden şüphe etmediği gibi bu konuda şüphe uyandıran düşünürleri de eleştirmekten çekinmeyecek, Platon'un ruh-beden düalizmini de, görünür âlemin gerçekdışı olduğu tarzındaki felsefi nazariyesini de reddedecektir. ${ }^{100}$

İkbal'in güce karşı duyduğu derin saygı, onun peygamber tasavvurlarına dahi yansımaktadır. Bundan dolayı olacak ki bir eserinin ismini Darb-ı Kelim ( Musa'nın Vuruşu) koyacaktır. Yine krallığı ve gücüyle peygamberler arasında temayüz eden $\mathrm{Hz}$. Süleyman da onun eserlerinde çok önemli bir rol oynamaktadır. İkbal'in hayranlığını celbeden diğer kahramanlar da hep güçleriyle temayüz eden isimlerdir. Bunlar arasında $\mathrm{Hz} \mathrm{Ali}^{101}$, Hâlid b. Velîd ${ }^{102}$ gibi sahabîlerin yanında Gazneli Mahmut ve Timur gibi hükümdarlar hatta hareketin, gücün ve mücadelenin sembol isimleri olmaları yönüyle Napolyon ve Mussolini gibi Müslüman olmayan liderler de bulunmaktadır. ${ }^{103}$

Yaşam, savaşmak ve galip gelmek arzusundan ibarettir, huzur vuruşmak ve çekişmektedir. ${ }^{104} \mathrm{Ikbal}$ 'in bu düşünceleri organik âlemdeki tekâmül için sürekli savaş ve güç kullanmanın gerekliliğini savunan Bergson'un fikirleriyle ${ }^{105}$ paraleldir. İkbal güç ve zayıflık konusundaki değerlendirmelerinde çıtayı daha da üste çıkaracak ve zayıflığı bir erdemsizlik olarak nitelendirecektir. O kadar ki İkbal açısından yaratıcı kuvveti olmayanlar Allah indinde kâfir ve zındıktan başka bir şey değildir. ${ }^{106}$ Onun güce verdiği değer, hayvanlara bakışını da belirlemektedir. Mesela gücü temsil etmesi açısından kuşlar arasında şahin onun dikkatini ve hayranlığını kazanmaktadır. Ona göre şahin sadece gücü değil, özgürlüğü ve yüksek idealleri de sembolize eder. Şahin, yaptığı yuvaya bağlanan sıradanlığın ve alışkanlıkların bağıyla kayıtlı değildir. ${ }^{107}$

İkbal, insandaki arzuları terk etmeyi bir erdem olarak gören mistik anlayışları da eleştirmektedir. Ona göre bu mistik anlayışlar, güçlü aslanı koyun haline getirmek ve onun savaşçı karakterini bozmaya çalışmaktan başka bir şey yapmamaktadırlar. Konu, gücün ve savaşın sembolü olan aslan ile itaatin ve zayıflığın sembolü olan koyun üzerinden anlatılır. Bir koyunun barış çığlıkları aslanı yolundan döndürmemelidir, çünkü kâinatta asıl olan savaştır, arzulardır. Savaşma ve arzunun terkedilmesi, benliğin çürümesi demektir. İkbal, arzulardan siyrılmayı telkin eden Platon'u da bir koyun olarak görmekte ve onun uyutucu saydığ düşüncelerini tehlikeli bulmaktadır. Platon'un "idealar âlemi” dediği "âyân-1 sâbite” ona göre sadece ölü ruhlar için anlamlıdır. íkbal,

99 İkbal, Câvidnâme, 254-255.

100 Aydın, “i̇kbal’in Felsefesinde İnsan”, 88.

101 Schimmel, Muhammed İkbal, 142.

102 Schimmel, Muhammed íkbal, 192.

103 Muhammed İkbal, Cebrail'in Kanadı, çev. Ahmet Kızılkaya (İstanbul: Kırkambar Yayınları, 2000), 144-145. Gerek Timur gerekse Mussolini hakkındaki düşünceleri sonraları değișecek, idealize edilen "güç” kavramı, gücün zulmün kaynağ1 olduğunda eleştirilecektir.

104 İkbal, Cebrail'in Kanadı, 97.

105 Bergson, Yaratıcı Tekâmül, 169.

106 Schimmel, Muhammed İkbal, 226.

107 Schimmel, Muhammed İkbal, 145. 
insanlardaki savaşçı fitratı bozan, ondan arzularını öldürmesini isteyen her türlü düşünce sistemine karşıdır ve bunları bir tür "afyon” olarak görmektedir. Dolayısıyla da Platon'un fikirleri ona göre insanları çalışma ve mücadele etme zevkinden mahrum eden zehirli şarap gibidir. ${ }^{108}$

İkbal, evrim teorisinin öngördüğü dinamik ve gelişmeye açık hayat anlayışına ters düştüğünü düşündüğü İslâm düşünce geleneklerini de eleştirmekten çekinmeyecektir. Bireyi ve toplumu pasifize eden, donuklaştıran, ilerlemeye ve gelişmeye engel olan her şey onun eleștiri oklarının hedefi olacaktır. Asıl istenen istikrar değil, ilerleme, büyüme ve mücadele içinde olmaktır. Evrimci ilerleme anlayışını, şair-düşünür bütün benliğinde hissettiğinden dolayı bu coşkuyu engelleyici her türlü düşüncenin de karşısında olacaktır. Gelişme, ilerleme ve bunun gereği olan mücadele etmek yoksa yozlaşma kaçınılmazdır. İkbal, gerek İslâm kültürünün yozlaşmasından gerekse Güney Asya Müslümanlarının çöküşünden, Platon felsefesinden etkilenen mistik acem şiirini sorumlu tutacak kadar eleştirilerini abartılı bir şekilde sertleştirecektir. Ona göre bu tasavvuf destekli şiir anlayışı, yaşamın dinamizmini yok ederek pasif duruşu bir erdem olarak pazarlamıştır. Artık benlik ve özgüven, kibir; acziyet ve dünyadan uzak durmak bir erdem kabul edilmiştir. Hakikatte olumlu anlamlarına rağmen tasavvufî dil aracılığıyla tevekkül, kanaat, rıza ve teslimiyet gibi kavramlar dahi bağlamından çıarılmış ve Müslümanların dünya işlerini önemsememesine yol açılmıştır. Bu haliyle halk arasında yayılan bu kavramlar, hem benliğin gelişmesine engel olmakta hem de dünya işlerinde insanları amaçsız ve arzusuz bırakmaktadır. Netice itibariyle Müslüman halkların eylemsizliğinin faturası halk tabakalarına kadar sirâyet eden vahdet-i vücutçu tasavvuf felsefesine kesilmektedir. Burada bu düşüncenin halk kitlelerine yayılmasındaki etkisi göz önüne alınmış olacak ki İranlı mutasavvıf şair Hâfız-1 Şîrâzî hedefolarak seçilmiştir. Bu eleştiriler sadece tasavvufla sınırlı da değildir. Pratik yaşama bir katkısı olmaması -dinamik yaşamı desteklememesi ve teşvik etmemesi-açısından bir ilim olarak Kelâm da onun eleştirilerinin hedefi olacaktır. ${ }^{109}$

İkbal'in bu yargılamalarının temelinde, benlik felsefesi, dinamik yaşam anlayışı ve yaratıcı tekâmül görüşü vardır. Onun bu yaşam felsefesi, yaşadığı dönemin şartlarından elbette bağımsız değildir ve İkbal, zayıflamış İslâm devletlerini ve Müslüman kitleyi uyandırmaya yönelik pratik bir amaç gözetmiştir. İslâm'ın temel metinlerine sadık kalmayı ilke edinen İkbal, bu metinlerle çağdaş düşünceleri uzlaştırma çabasında bir düşünce karmaşasına sürüklenecektir. Hayatta tek bir kanun vardır o da güçtür. ${ }^{110}$ Derken İkbal, zayıflığı, tembelliği fakirliği kendi evrimci teorisi adına mahkûm ederek bunların ahlâkî birer zaaf olduğuna hükmeder. ${ }^{111}$ Gerek maddi gerekse manevî fakirlik bu güç kanununa göre yok olmanın sebebidir. Hayat savaşında yenik olarak çıkanlar, yokluğa gömülmektedirler. o kadar ki íkbal'e göre yersiz affetmek bile hayat coşkusunu söndürmekte, kâinatın düzenini bozmaktadır. Güçsüzlük, içerisinde hiçbir iyilik barındırmayan kötülüğün kaynağıdır. ${ }^{112}$ Miskinlikten kaynaklanan fakirlik, şairi bıktırmıştır. ${ }^{113}$ Dolayısıyla evrim

108 İkbal, Benlikve Toplum, 48.

109 Soydan, İkbâl'e Dair, 99-105.

110 İkbal, Benlik ve Toplum, 63.

111 İkbal, diğer dinlerle İslâm dinin farklarını gösterirken İslâm'ın bir din olarak fakirliği kötü gördüğünü iddia edecektir (İkbal, “Ahlâkî Bir İdeal Olarak İslâm”, Makaleler, 200).

112 İkbal, Benlikve Toplum, 63.

113 İkbal, Cebrail'in Kanadı, 32. 
teorisinin yol açtığı ahlâk anlayışı, İkbal'i ahlâk felsefesinde de değişiklikler yapmak zorunda bırakır. Güçsüzlüğün merhamet, hoşgörü ve tevazu kıllğına girerek karşımıza çıkmasına aldanmamamızı öğütleyen ${ }^{114}$ İkbal'in dili, merhameti, erdemsizlik olarak gören Nietzsche'nin (1844-1900), nihilist ahlâk tasavvurunu çağrıştırsa da ${ }^{115}$ İkbal, güce verdiği bu mutlak değeri revize edecek ve hiçbir ahlâkî ilke gözetmeyen güç kullanımını reddedecektir. Kendi aç gözlülüğüyle binlerce tok insanı aç bırakan kralı insanlı̆̆ın düşmanı olarak gören ${ }^{116}$ İkbal, güçleriyle temayüz eden Timur ve Cengizhan'ı da zalimlikle itham etmektedir. ${ }^{117}$

\section{4. İkbal'in Evrim Teorisi Bağlamında Bazı Kelâmî Kavramları Yorumlayışı}

İkbal'in yaratıcı evrimci felsefesinde insan, evriminin ilk aşamalarında arzu ve içgüdüyle idare edilmekteyken, aklın gelişimiyle çevresinin efendisi olacaktır. İkbal, nübüvveti dahi bu teori paralelinde temellendirir. Buna göre İslâm peygamberi, kadim ve modern dönem arasında durmaktadır. Kaynağı kadim döneme ait olan vahyin ruhu modern döneme aittir. İkbal, Kur'an'ın sürekli akla, tecrübeye, tarihe, tabiata yaptığı vurguya dayanarak İslâm'ın doğuşunu tümevarımcı aklın doğuşu olarak kabul etmiş ve peygamberlik müessesinin kaldırılmasını da buna bağlamıştır. Artık Kur'an'ın belirttiği üzere Allah'ın âyetleri hem derûnî hem de haricî tecrübede görülecek, ${ }^{118}$ Hatm-i nübüvvet konusu böylece evrim teorisiyle ilişkilendirilerek aklî bir zemine oturtulmaya çalışılacaktır.

İkbal'in bu tekâmülcü insan ve evren anlayışının doğal bir sonucu olarak irade sorunu da gündeme gelmektedir. İkbal'in ego tasavvurunda insan eylemlerinden tamamen sorumlu olan özgür bir öznedir. Egosunu güçlendiren özgür birey, aynı zamanda kendi kaderini de kendisi tayin edecektir. ${ }^{119} \mathrm{Bu}$ özgürlük insana Allah tarafından verilmiştir. İkbal'in "ruhanî çoğulluk" şeklindeki âlem anlayışında mutlak ben olan Allah, maddeden insana kadar uzanan benlik vasfına sahip varlıklar yaratır, bütün varlık mertebelerinde benlik vardır. Onun düşünce sistemindeki bu "benler" Leibniz'in monadları gibi birbirine kapalı olmayıp sürekli ilişki içinde bulunan “organizmler"dir. Bütün bu benler içinde Tanrı'ya en yakın olan insandır. Bu ilişkiler ağı içinde maddî âlem, biyolojik âlemle, biyolojik âlem, psikolojik âlemle neticede hepsinin Allah'la bağlantısı vardır. ${ }^{120}$

İkbal'in evrim teorisi yorumunda insanın özgürlüğü, şer problemi, Tanrının âlemle olan ilişkisi gibi birçok kelâmî sorun da çözülmeye çalışlır. Khtoon'un dikkat çektiği üzere evrensel determinizm ve buna bağlı olarak insanın özgürlüğü sorunu bu bakış açısıyla temellendirilir. Buna göre evrimsel süreç içerisinde egonun özgürlüğü, onun gelişimine paralel olarak artmakta ve

114 İkbal, Benlikve Toplum, 64.

115 Friedrich Nietzsche, Güç İstenci45-47.

116 İkbal, Benlikve Toplum, 79.

117 İkbal, Cebrail'in Kanadı, 22.

118 İkbal, İslâm'da Dinî Düşüncenin Yeniden İnşası, 163-164.

119 Schimmel, Muhammed İkbal, 75, İkbal'de insanın özgürlüğünü ele alan bir çalışma için bk. Aydın, "Süreç Felsefesi Işı̆̆ında Tanrı-Âlem İlişkisi”, 31-87.

120 Aydın, “íkbal'in Felsefesinde Allah-Âlem İlişkisi”, 109; Aydın, “Süreç (Proses) Felsefesinin Işı̆̆ında”, 42. 
böylece ego determinizmin belirleyici etkisinden kurtulmaktadır. Maddeden hayata ve zihne geçiş, zorunluluk ve determinizmden, özgürlük ve bağımsızlığa hareket anlamına gelmektedir. ${ }^{121}$

İkbal'in yaratıcı evrim teorisi bir yaratıcı kudretin iradesine bağlı ve bir amaca yöneliktir. İkbal, modern evrim teorisinin temel tezlerinden olan, ilahi iradeden bağımsız doğal seçilim ilkesinin yerine, kendi sonsuz imkânlarını gerçekleştirmek için bütün evrimsel sürece müdahale eden ve hayatın sürekli yukarı doğru olacak şekilde yürüyüşünü belirleyen fail bir kudreti koyar. ${ }^{122}$ Zayıflara yaşam hakkı tanınmayan İkbal'in evrimci felsefesinde de daha yüksek bir hayatla varlığını sonsuzca devam ettirecek olanlar sadece güçlülerdir. ${ }^{123}$ Insanın ölümsüzlüğü yaptığ 1 seçimlere, egonun gelişmesine; kaderi, özgürce seçimine ve yaratıcı faaliyete katılmasına bağlıdır. Benliğini geliştiren insan, Allah'ın halifeliği makamına gelecek ve Allah'ın iradesine tesir edecektir. Kendisi için yazılan kaderin nihai şekillendiricisi insandır ve her kader yazımından önce Allah kuluna rızasını sormaktadır. ${ }^{124}$ Fakat böyle bir yorumda nihai egonun -Allah'ınözgürlüğünü kısıtlamak tehlikesi olduğu için İkbal, bu sınırlandırmayı ilahi hikmetin gereği sayacak ve ulûhiyet açısından burada bir sorun görmeyecektir. Ona göre sınırlandırılmayan kudret, kör ve keyfi bir hal alacaktır. Egonun varlığını sürdürmesi İkbal'in tekâmül nazariyesine uygun olarak çevreye karşı verdiği mücadeleye ve direnişe bağlıdır. Onu hayatta tutan, gösterdiği direnç ve sürekli var olan bir gerilim halidir. Egonun bu gerilimi ve mücadeleyi bırakarak gevşemesi onun çözülmesiyle neticelenecektir. İnsanın bu yok oluştan kurtulması ancak gerilimin son notasına ulaşarak güçlenmesi ve varlığın merkezinde bir yer edinerek ölümsüzleşmesiyle mümkündür. Ölümsüzleşme meselesinde anlaşıldığı kadarıyla İkbal'in en zorlandığı mesele cehennem inancıdır. Bundan dolayı İkbal, zayıf olan ve gelişmemiş egoları mutlak yokluğa göndermez. Cehennem bir 1slah yeri olarak bu zayıf egoları beklemektedir. İkbal'in berzah inancından anladığı ölümden sonra gelişen ruhların diğer hayata geçerek yolculuklarına devam etmesidir. ${ }^{125}$ Ikkbal'in Cavidnâme'deki miraç yolculuğunda Zuhal feleğine söylettiği "bazı insanları cehennemin bile yakmaktan nefret ettiği ve bu insanların kıyameti dahi hiç göremeyeceği" 126 ifadeleri, düşüncelerindeki tutarsızlığı mı yoksa şairâne bir mübalağayı mı gösterdiği açık değildir. Her hâlükârda Azmî’nin vurguladığı gibi İkbal'in insan felsefesi varoluşçu düşünürlerin insan anlayışlarıyla temelde benzer noktaları varsa da düşünür, ölüme bakış açısıyla onlardan kesin olarak ayrılmaktadır. İkbal'de ölüm insanın korkması gereken bir konu olarak görülmemektedir. ${ }^{127}$

Modern evrim teorisinde ruh-beden ayrımını daha doğrusu ruhun bedenden müstakil varlığı sorununu ìkbal, ruhun varlığını inkâr etmeden bedeni ve ruhu eşitleyecek bir ruh tanımıyla aşmaya çalışmakta, geleneksel ruh ve beden düalizmine yönelik temelli bir itiraz yöneltmektedir. Onun ruhtan tam olarak kastettiği "ben"dir, beden de yaratıcı, dinamik ve canlı gücün

\footnotetext{
121 Khatoon, İkbal'in Felsefe Sisteminde Tanrı İnsan ve Kâinat, 132.

122 Khatoon, İkbal'in Felsefe Sisteminde Tanrı İnsan ve Kâinat, 133,

123 Khatoon, İkbal'in Felsefe Sisteminde Tanrı Insan ve Kâinat, 167.

124 Soydan, İkbâl'e Dair, 104-105.

125 Khatoon, İkbal'in Felsefe Sisteminde Tanrı İnsan ve Kâinat, 153-176.

126 Schimmel, Muhammed İkbal, 205.

127 M. Yusuf Azmi, “İkbal'de İnsan Kavramı”, çev. Mustafa Alıcı, İkbal'in Düşünce Dünyası, ed. Ahmet Albayrak (İstanbul: İnsan Yayınlar1, 2004), 189-190.
} 
nesneleşerek görünür olması ve iradenin belli amaçlarını gerçekleştirmesi için vücud kazanmış halidir. Beden, birikmiş bir eylem ve ruhun alışkanlığı olarak ondan ayrılamaz ve bilincin bir unsuru olarak varlığını korur. Onun ruh nazariyesine göre ruh-beden ilişkisi Tanrının kâinatla olan ilişkisi gibidir. Kâinat Tanrının; beden de ruhun nesneleşmesidir. Bedenin kaynağı ruh, ruhun kaynağı Tanrıdır. Ruhun bedende belirli bir yeri olmadığı gibi bedenle özdeş de değildir. Bedenin her bir atomuyla ilişki halinde olan ruh, bedenin ne tam içindedir ne de dışındadır, bedenin her atomuyla ilişki halinde olmasına karşın bedenin ötesindedir ve her türlü bedene etki etmektedir. ${ }^{128}$ İkbal'in ruh-beden düalizmini aşmaya yönelik bu yorumları her ne kadar bilimsel evrimin sonuçlarıyla uyuşmasa da bedene yüklenen bu yüksek itibar, geleneksel beden algısını yıkacak düzeyde radikal bir hamledir. Artık beden ruhun emrine kullanılmak üzere verilen basit bir araç değildir. Beden, maddenin evrimleşerek geldiği en yüksek seviyenin yeryüzünde vücûd bulmasıdır.

Dinî metinlerde insanın çıkış yeri olarak bahsedilen cennet, ona göre duyuüstü bir mekân değil, insanın basit bilinç durumuna yapılan bir göndermedir. Âdem de cennette yaratılan ve yabancı bir âleme sürgüne gönderilen somut bir insan değildir. İkbal'e göre Âdem'den kastedilen Tanrı'nın vekili olabilecek insandır. Ona göre insanın kaynağı dünyadır. İnsanın cennetten düşmesi, ilkel halinden özgür ben konumuna yükselmesi olarak yorumlanır. ${ }^{129}$ Böylece "insanın göksel bir varlık olup tabiata ait olmadığı ve hayvanlardan ayrıcalıklı olduğu" ${ }^{130}$ tarzında evrim teorisine yönelik eleştirilerin önüne geçilmekte ve evrim teorisine uygun olacak şekilde insan tabiatın bir parçası olarak kabul edilmektedir.

Egonun gelişmesi adına zayıf olanların yok edilmesini isteyen, sürekli savaşı ve bunun kaçınılmaz sonucu olarak bütün tercihlerinde kişisel çıarını düşünen ${ }^{131}$ insan, İkbal'in idealize ettiği bir insan modelini tam olarak göstermese de İkbal'in gelişmek için mücadele etmeye mahkûm egoları, Darwin'de "var olma savaşı" ${ }^{32}$ teziyle paraleldir. Evrimsel süreçteki bu var olma savaşı, İkbal'in birçok dinî kavrama yaklaşımında belirleyici rol oynamaktadır. Bundan dolayı İkbal, cihadın artık kılıçla değil, kalemle olması gerektiğini söyleyen din bilginlerini korkaklıkla itham edecektir. Ona göre ölümün tatlllığının idrakinde olan, cihadı terk etme telkinlerinden etkilenmez, kalemle cihat, sadece ölümden korkanlar içindir. ${ }^{133}$

\section{5. İkbal'in Evrim Teorisi Konusundaki Çelişkileri ve İkbal'e Yönelik Temel Eleştiriler}

İkbal'in evrim yorumunda modern evrim teorisiyle tasavvuf felsefesinin bir sentezi yapilmakta ve

\footnotetext{
128 Khatoon, İkbal'in Felsefe Sisteminde Tanrı İnsan ve Kâinat, 145-152.

129 Khatoon, İkbal'in Felsefe Sisteminde Tanrı İnsan ve Kâinat, 133-134.

130 Mesela Aliya İzzetbegoviç, evrim teorisine yönelik temel eleştirilerini insanın göksel ve irrasyonel bir varlık olduğu tezine dayandırmaktadır (bk. Aliya İzzetbegoviç, Doğu ve Batı Arasında İslâm, çev. Salih Şaban (İstanbul: Nehir Yayınlar1, 2006), 47-73).

131 Charles Darwin, Türlerin Kökeni, 109.

132 Darwin, Türlerin Kökeni, 201.

133 Sekban Halifat, “íkbal'in İhya Projesinin Analizi”, Muhammed İkbal Kitabı Uluslararası Muhammed İkbal Sempozyumu Bildirileri (İstanbul: İstanbul Büyükşehir Belediyesi Kültür İşleri Daire Başkanlığı Yayınları, 1997), 154-197.
} 
bu teori onun elinde mistik-metafizik bir renge bürünmektedir. Fakat bu mistik tavırda evrim teorisindeki hayat mücadelesi, doğal seçilimdeki acımasızlık aynen korunmaktadır. Onun modern evrim teorisine en temel itirazı ise bu kuramın hükmünün yaşamla sınırlı olması ve ölüm sonrasına aksetmemesidir. Modern evrim teorisi reddedilmese de olduğu gibi de kabul edilmemekte, metafizik bir muhteva ve şiirsel bir dille yeniden üretilmektedir. Bu sentez düşüncesi aynı zamanda onun çelişkilerinin de temel nedeni gibi durmaktadır. İkbal'in çelişkilerinin temelinde akıl-vahiy uzlaşmasının yaratıı̆̆ sorunların yanında, birçok düşünce adamında olduğu gibi düşünce serüveninde farklı dönemlerindeki değişimlerin de rolü vardır. ${ }^{134}$ İkbal'in kendisi de "çelişkiler topluluğu" olduğuna dair yapılan eleştirilerin farkındadır ve bu durumdan rahatsız da değildir, ${ }^{135}$ düşünür, çelişkiler içerisinde olduğunu kabul etmektedir. ${ }^{136}$ İkbal teorik olarak tutarsızlıklarının yanında pratik hayattaki tutarsızlıklarının da bilincindedir ve bundan dolayı "Kendine Nasihat" başlığı altında bu durumu dile getirmekten ve özeleştiri yapmaktan da çekinmemektedir. ${ }^{137}$ Gerek pratik hayatında gerekse düşüncelerindeki çelişkilerin farkında olan İkbal, durumunu savunma gereği duymayacak kadar bu çelişkileri kişiliğinin bir parçası olarak görmüştür. İkbal, bir şair ve hatip olduğunu dahası mistik bir etki altında olduğunu ima etmesi ${ }^{138}$ çelişkilerinin beslendiği kaynağı göstermesi açısından ayrıca önemlidir.

Hayatın sürekli bir mücadele ve coşkunluk olduğunu düşünen İkbal, evrim teorisine uygun olan Batı'daki rekabetçi toplumsal yapıyı onaylayacak mıydı? İşte tam bu noktada İkbal, güç ve başarıya verdiği değerin âdetâ sonuçlarıyla yüzleşmekten kaçınmakta, güç ve başarının sadece bunlar Müslümanlarda olduğunda değerli kavramlar olduğunu ima etmektedir. İkbal'in güç, başarı, rekabet ve mücadele kavramlarını yücelttiği halde Batı toplumundaki rekabetçi yaşam felsefesini, sömürgeciliği ve bencilliği eleştirmesi ${ }^{139}$ herhalde düşüncelerindeki tutarsızlık ve değişimlerle açıklanabilir. ${ }^{140}$ Anlaşılan İkbal, biyolojik evrim üzerine kurulacak bir ahlâk anlayışının pratik hayattaki sonuçlarını, ortaya çıkan acımasızlığı kabul etmekte zorlanmaktadır ve bu evrimsel yaşam felsefesi onun ahlâk ve maneviyat anlayışına ters düşmektedir. Bundan olsa gerek İkbal, Darwinci evrim teorisinden hareket ettiği için Nietzsche'nin acımasız ve sevgisiz “süper insanı"nı, "süper-hayvan" olarak görmektedir. İkbal, Doğu'dan da Batı'dan da, geçmiş ve şimdiden de etkilenmekte ve bütün bunların katkısıyla kendi düşünce sistemini örmeye çalışmaktadır. Onun düşüncesinde dogmatik duvarlar pek yoktur. Bir düşünüre veya bir düşünce sistemine sadakatle bağlanmadığ $1^{141}$ gibi kendisi de tutarlı bir düşünce sistemi kuramamaktadır. Önemli bir İkbal uzmanı ve hayranı olan Schimmel (1922-2003), ìkbal'deki çelişkileri onun sistemli bir filozof değil,

134 İkbal uzmanları onun fikrî süreçlerini temelde dört döneme ayırmaktadırlar (Soydan, İkbâl'e Dair, 310).

135 ìkbal, Hareket Zili, 52.

136 "Ey îkbal, garip bir çelişkiler bileşkesisin/Hem tek başınasın, hem de mahfilin rengisin" ìkbal, Hareket Zili, 104.

137 "Ben İkbal'e nasihat yollu şunları söyledim: Ne amelinde oruç var, ne de namaza bağlssın Sen de riyakârlar tutumunda kâmilleștin/ Gönülde Londra arzusu, ama hicaz der dolaşırsın” ( İkbal, Hareket Zili, 153).

138 "Ben de gerçekte ne olduğumu bilmiyorum/Benim düşünceler denizim çok derindir. Ben de istiyorum ki ìkbali göreyim/Ondan ayrı kaldığıma çok gözyaşı dökerim İkbâl de henüz İkbal'e âgâh değil/Hiç̧ şaka yok bunda vallah değil” ( İkbal, Hareket Zili, 52).

139 Soydan, İkbâl'e Dair, s, 82

140 İkbal'in değerler anlayışı da kalıcı ve tutarlı değildir. Mesela bir dönem vatanın çıkarlarını, hayrın-şerrin, hakkınbatılın ölçüsü olarak görmesi vatan telakkisinin değişmesiyle birlikte değişecektir (Soydan, íkbâl'e Dair, 85-91).

141 Halife Abdülhakim, "Muhammed İkbal", çev. Yusuf Ziya Cömert, İslâm Düşüncesi Tarihi, ed. M. M. Şerif - Mustafa Armağan (İstanbul: İnsan Yayınları, 1991), 4/ 406. 
"peygamberâne" bir düşünür olmasına bağlar. ${ }^{142}$ ìkbal'in, eserlerindeki çelişkilerin ${ }^{143}$ yanında Aydın, onun bilime dair değerlendirmelerinde de yanlışlıklar olduğunu da iddia etmektedir. ${ }^{144}$

Düşünürün evrim teorisi bağlamında içtihat-taklit ve düşünce özgürlüğü konusundaki düşüncelerinde de çelişkiler bulunmaktadır. Oysa içtihad onun evrim görüşü dikkate alındığında merkezi bir öneme sahiptir. Herşeyden önce içtihad, gelişmeyi, ilerlemeyi ve değişimi öngördüğünden dolayı bütün bunları tersine çevirecek şekilde pasifize olmayı, yerinde saymayı, donuklaşmayı ve yozlaşmayı doğuracak taklidin karşısındadır. İkbal anlaşılan zihni bir karmaşa içindedir ve bu da onu ister istemez tutarsızlıklara düşürmektedir. Şair-düşünür evrimci görüşleriyle dinî görüşleri arasında bocalamakta ve içtihad düşüncesinin yol açacağı yeniliklerin nelere mal olacağı noktasında güvensizlik içinde kalmakta ve bütün eleştirilerine rağmen geleneğe bağlllığını büyük bir duygusallıkla sürdürmektedir. Gelişme ve değişme düşüncesi gelenekten kopmayı ihtiva eden yönüyle düşünürü tedirgin etmektedir. Meselâ Türkiye'deki Cumhuriyet dönemiyle gerçekleşen siyasî ve kültürel dönüşümü tevarüs eden entelektüel geleneğin başarılı bir yorumu ve hatta bir İslâm Rönesans'ı olduğunu düşünecek ve bunu kendi ülkesinde gerçekleștirmek isteyecek kadar heyecanla ve öykünmeyle karşılasa $\mathrm{da}^{145} \mathrm{bu}$ yenilenmenin muhtevasından ve sonuçlarından dehşete kapılacak ve sert eleştiriler yöneltecektir. ${ }^{146}$ Gerileme döneminde birlik ve beraberliği korumak ve ihtilafa düşmemek adına içtihat fikrine karşı çıkarak öncekilerin yoluna bağlanmamızı öğütleyen ve taklidi bir çare olarak sunan ${ }^{147} \mathrm{ikbal}$, bir başka eserinde taklidin iyi bir şey olsa bizzat peygamberin atalarını taklit etmesi gerektiğini söylemektedir. ${ }^{148}$ İkbal'in oğlu Cavid İkbal de babasının şeriatın muamelat kısmının modern ihtiyaçlara göre yenilenmesi gerektiğini düşündüğünü söylese de ${ }^{149}$ İkbal, içtihat fikrine İslâm birliğini parçalayacağı gerekçesiyle sıcak bakmamakta ve hatta bu gerekçeye dayanarak düşünce özgürlüğüne dahi karşı çıkmaktadır. İkbal'de fert gibi toplumun da varlığını sürdürmesi ve yükselmesi savaşa bağlanmaktadır: Milletlerin kaderi ne? Sana söyleyeyim: Okla- kllı̧la yükselmek; udla- sazla yok olmaktır. ${ }^{150}$ Güç aynı zamanda özgürlüğü ve savaşı da beraberinde getirmektedir. Özgür insan, fitratında tekrara düşmek olmayan, alışkanlıkların zincirinden kurtulmuş ve kendi kaderiyle savaş halinde olan insan ${ }^{151}$ olarak tanımlansa da bu düşünceye de sadık kalınmamaktadır. Müslümanların birlikleri bozacağı endişesiyle içtihat fikrine soğuk bakan ve toplumsal kurtuluşu geleneğe sıkı sıkıya bağlanmakta gören İkbal, bununla tamamen çelişecek şekilde egonun gelişmesi için hiç kimseye bağlanmamayı öğütleyecektir. ${ }^{152}$ Fertle toplum

142 Schimmel, Muhammed İkbal,18

143 Schimmel, Muhammed íkbal, 228

144 Mehmet S. Aydın, “Genel Değerlendirme”, Muhammed İkbal Kitabı Uluslararası Muhammed İkbal Sempozyumu Bildirileri (İstanbul: İstanbul Büyükşehir Belediyesi Kültür İşleri Daire Başkanlığı Yayınları, 1997), 219-222.

145 İkbal, İslâm'da Dinî Düşüncenin Yeniden İnşası, 190

146 "Yenileşme yolunda seslenen mustafa (kemal) dedi ki: "Eski resme yeni cilâ lâzımdır!"/ Kâbe'nin hayat elbisesini yenileştirmediAvrupa'nın Lât ve Menatı ona geldiler”. ìkbal, Câvidnâme, 195.

147 İkbal, Benlikve Toplum, 148.

148 Schimmel, Muhammed İkbal, 85.

149 İkbal Cavid, “Cavid İkbal'in Açılış Konuşması”, Muhammed İkbal Kitabı Uluslararası Muhammed İkbal Sempozyumu Bildirileri (İstanbul: İstanbul Büyükşehir Belediyesi Kültür İşleri Daire Başkanlığı Yayınları, 1997), 18-27.

150 İkbal, Cebrail'in Kanad, 39.

151 İkbal, Benlikve Toplum, 89.

152 Schimmel, Muhammed İkbal, 227. 
arasındaki ilişkiyi yaprakla ağaç arasındaki ilişkiye benzeterek ağaçtan kopan yaprağın çürüyeceği gibi toplumdan kopan ferdin de yok olacağı imasını yapmaktadır. ${ }^{153}$ Bireyin özgürlüğünün en büyük tehdidi olan toplumu, bireyin var olmasının şartı olarak gören İkbal; birey-toplum ilişkisini damla-deniz metaforuyla açıklayacaktır. Denize katılan damla yok olmayacak aksine daha da güçlenecektir. ${ }^{154}$ Birey kendi potansiyelini millet içinde bulacak ve daha da güçlenecektir. Millet içinde kendini eriten birey, deniz kadar büyüyen bir damla olacaktır. Birey toplumun ona yüklediği bütün görevlerini yerine getirmeli, birey toplumun kural ve kurumlarına sadık kalmalıdır, dahası bireyin benliğini koruması dahi toplumla olan ilişkisine bağlanmıştır. Birey toplumun bütün etik kurallarına da uymalıdır. ${ }^{155}$ Bireyin varlığı mecaz, toplumun varlığı ise gerçektir. Birey kendini millete feda ederek bu mecaz büyüsünü bozmalıdır. ${ }^{156}$ İkbal, evrim teorisini sadece ferdin gelişimi için değil toplumun gelişimi için de bir hareket noktası olarak görmektedir. Bundan dolayı "Toplumun Evriminde Bir Etken Olarak Dinin Anlamı" isimli bir konferans verecektir. ${ }^{157}$

Birey-toplum arasındaki ilişkiyi bu şekilde tayin eden İkbal, bu kadarla da yetinmemekte, toplumun birlik ve beraberliğini sağlamak adına bireyden başka fedakârlıklar da istemektedir. Bunlardan belki de en dikkat çekeni düşünce özgürlüğü hakkındaki fikirleridir. Evrimci düşüncenin kaçınılmaz sonucu olan özgürlük konusunda da İkbal'i yine tutarsızlıklar içinde görmekteyiz. Onun tarafından değişik gerekçelerle adetâ lanetlenen düşünce özgürlüğü, tam bununla çelişecek şekilde İkbal'in değerler hiyerarşisinin en üstlerinde yer alacak kadar vazgeçemediği bir değerdir ve düşünürün bizatihi hayatı ve düşünceleri bunun en önemli kanıtıdır. Modern zamanların ikilemler içinde kalan bir kısım Müslüman aydınları gibi o da geleneğin değer yargılarıyla modern zamanların değer yargıları arasında tutarlı olacak şekilde tercihlerini belirleyememektedir. İkilemler içinde kalan İkbal, kendisi için istediğini diğer insanlar için istememekte ve bu konuda da bizi şaşırtmaya devam etmektedir. Her türlü fikrin özgürce ifade edilip savunulmasını "şeytânî" bir eylem olarak gören İkbal'e göre özgürlük, toplumun yüksek menfaatleri açısından zararlıdır. ${ }^{158}$ Sonuçta, fert topluma kurban edilmiş ve toplumsal maslahat uğruna bireyin düşünce özgürlüğü şeytanî bir iş olarak görülmüştür. İkbal'in özgürlük tutkusu ${ }^{159}$ ironik bir şekilde onun düşünce özgürlüğüne karşı çımasına engel değildir. Oysa özgür, yenilikçi ve hatta reformcu olmak İkbal'de idealize edilen kâmil insanda olması gereken özellikler olarak sıralanır. Bu ideal insan, içinde bulunduğu zamanla çatışma halinde olan entelektüel bir tiptir. "Merd-i mümin" dediği bu Müslüman insan, gerçek niteliklerini ancak tam özgür toplumsal çevrede gerçekleştirebilmektedir. ${ }^{160}$ Tasavvuftaki egonun -bireyin- Tanrı'da yok olması görüşünü eleştiren İkbal, tam da bununla çelişecek şekilde fert-toplum ilişkisinde benzer bir düşünceyi savunmaktadır. Bütün bağlardan, alışkanlıklardan ve taklitten kurtarmaya ve

153 İkbal, Benlikve Toplum, 102.

154 “Birey millet birliği ile kaim, tek başına hiçtir; dalga denizde dalgadır, deniz dışında hiçtir.” (İkbal, Hareket Zili, 163).

155 Soydan, İkbâl'e Dair, 124-131.

156 İkbal, Hareket Zili, 113.

157 İkbal, Mektuplar, 50.

158 Soydan, İkbâl'e Dair, 132.

159 Soydan, İkbâl'e Dair, 227.

160 Soydan, İkbâl'e Dair, 140-142. 
özgürleştirmeye çalıştı̆̆ ferde, toplum içinde eriyerek toplumla bütünleşmesini öğütlemekte, benliğini korumak isteyene, benliğini toplum içerisinde eritmeyi tavsiye etmektedir. ${ }^{161}$

İkbal'in ego anlayışı ve evrimci düşünce tarzı dinî metinleri yorumlarken sadece geleneksel kalıpları ve metnin zahirini zorlamakla kalmaz, bir kısım tutarsızlıklara da neden olur. İkbal'in evrim teorisiyle şekillenen düşünce sistemi şehzad Kayser tarafından birçok yönden eleştirilecektir: İkbal'in cenneti bir mahal değil, bir hal olarak görmesi, kişisel ölümsüzlüğü şahsi gayrete bağlaması ve böylece ebediliği sadece kâmil insanlara hasretmesi, kendisi her ne kadar teist olsa da ego felsefesinin doğal bir sonucu olan panteist bir Tanrı tasavvuruna kapı aralaması, ölümsüzlüğü insanın seçimine ve mücadelesine bağlaması ve cehennemi sonsuz olmayan bir ıslah tecrübesi olarak değerlendirmesi, Kur'an'daki Tanrı tasavvurlarıyla açıkça ters düşmesine rağmen, Tanrı'nın insana özgür irade vererek risk aldığını iddia etmesi, İnsan-1 kâmil kavramını İslâm geleneğiyle bağdaşamayacak şekilde kendi evrimci görüşüne göre şekillendirmesi, buna göre insanın halife olması dahi bir realite olarak değil, evrimsel sürecin sonunda insanın varacağ 1 nokta olarak görmesi, kendi evrim teorisi anlayışına uygun olacak şekilde güce değer atfetmesi ve bundan dolayı Nâdir Şah ve Mussolini gibi aksiyon insanlarını Hâfız-1 Şîrâzî gibi sûfîlere tercih etmesi, peygamberlerden dahi tarihe müdahale edebilen cephesiyle özellikle Hz. Musa'ya sayg1 duyması ${ }^{162}$ yazarın İkbal'e yönelttiği başlıca eleştiri noktalarıdır.

İkbal'in evrimsel sürece dair rasyonel izahlarını "yanlış mecralara dökülmüş teşebbüsler" olarak gören ve aslında İslâm evrimcilerinden etkilenerek böyle bir mecraya sürüklenmeye heves ettiğini ileri sürerek onun evrime dair düşüncelerini küçümseyen Kayser'in ${ }^{163}$ eleştirileri ve küçümseyici imaları, İkbal'in şahsında modern değerlere ve bilimsel bilgiye yönelik eleştirilerdir. Buradaki eleştiriler, ìkbal üzerinden evrim teorisine yapılmakta ve modern dünyayla bir hesaplaşmaya gidilirken araya onun evrimci fikirleri sıkıştırılmaktadır. ${ }^{164}$

\section{Sonuç}

İkbal'in yaratıcı evrim teorisi bütün düşünce sitemini ve değer yargılarını derinden etkilemekte ve dönüştürmektedir. Savaş, mücadele, hareket, güç başarı gibi kavramlar onda yüksek erdemler olarak sürekli takdir edilmekte, zayıflık, fakirlik, tembellik, sükûnet eleştirilmekte, savaşçı yaşam felsefesini teşvik etmeyen birçok tasavvufî ve felsefî düşünceye de cephe alınmaktadır. Savaşın güzelliğinden, acıların ve arzuların insanın gelişmesi için kaçınılmazlığından bahseden İkbal, dinginliği ve arzulardan kurtulmayı tavsiye eden felsefî ve mistik anlayışları da eleştirecektir. Her düşünce adamında olduğu gibi İkbal'de de düşüncelerinin gelişimi ve değişiminde yaşadığı dönemin şartlarının belirleyici rolü gözden kaçırılmamalıdır. Batı'nın ilerlemesi karşısında İslâm ülkelerindeki gerileme onun mücadeleyi, çalışmayı, gücü, gelişmeyi bir erdem olarak görmesine ve insanları öğretileriyle tembelliğe sürükleyen geleneksel düşünce sistemlerine savaş açmasına sebep olmuştur. Hindistan özelinde din-bilim tartışmalarının sonunda, İslâm'ın akıl ve bilimle

161 İkbal, Benlikve Toplum, 103.

162 Syed Vahidüddin, “Muhammed İkbal'in İslâm’a Yaklaşımı Üzerine Tenkitçi Bir Değerlendirme”, çev. Ünver Günay, İkbal'in Düşünce Dünyası, ed. Ahmet Albayrak (İstanbul: İnsan Yayınları, 2004), 247-261.

163 Şehzad Kayser, “ỉkbâl'in İslâm Kültürü Üzerine Eleştirel Bir Yaklaşım”, çev. Mehmet Süheyl Ünal, İkbal'in Düşünce Dünyasl, ed. Ahmet Albayrak (İstanbul: İnsan Yayınları, 2004), 271.

164 Bk. Kayser, “íkbâl'in İslâm Kültürü Üzerine Eleştirel Bir Yaklaşım”, 263-279. 
çelişmeyeceği düşüncesinin hâkim paradigma olması onun evrim teorisine yaklaşımında etkili olmuş, bilimsel bir teori olarak görülen evrim teorisinin din tarafından da yanlış görülemeyeceği hükmüne varılmıştır. İkbal bu teoriyi olduğu gibi değil, kendine özgü yorumuyla kabul etmiş ve bu teoriye metafizik bir muhteva yüklemiştir.

Elbette evrim teorisini kabul etmek bir düşünür için bu teorinin felsefî sonuçlarıyla yüzleşmeyi gerektirecek, İkbal özellikle inanç ve ahlâk alanında bu krizle mücadele etmek zorunda kalacaktır. Yaşamın bir savaş olduğunu iddia eden evrimsel görüşe paralel bir ahlâk anlayışına yanaşacaktır. Bundan dolayı İkbal, zayıflığı, başarısızlığı bir kötülük olarak tanımlayacak, güçlü olmayı haklı olmakla eşitleyecek, merhamet duygusunun insanı aldatmasının ihtimaline dikkat çekecektir. Yine de düşünür, merhametin bizatihi kötü olduğunu söyleyecek bir sonuca ulaşmamaktadır. Bu anlamda evrim teorisinin ahlâk açısından bütün olası sonuçlarını kabul etmeyen íkbal, ahlâk felsefesini doğadan çıkarmaya yönelik bir amacı olmadığı gibi Nietzsche gibi geleneksel ahlâk anlayışlarıyla toptan yıkıcı bir hesaplaşmaya girmek gibi bir niyeti de yoktur. İkbal, evrim teorisini dinamik insan anlayışına bilimsel bir zemin olarak kullanmakta, bu teorinin olası ahlâkî sorunlarıyla bütünüyle yüzleşmek istememektedir. İkbal, modern evrim teorisine metafizik bir içerik kazandırmaya ve bu teoriyi yeniden tanımlamaya çalışsa da tutarlı olmakta zorlanacak ve kendisiyle zaman zaman çelişmek durumunda kalacaktır.

Evrim teorisini kabul eden İkbal'in işi oldukça zordur. Hayatı, ölümü, yeniden dirilişi, berzahı, cenneti, cehennemi, iyi ve kötüyü ilk insan olan Âdem'i, Şeytan'1, şerri, özgürlüğü, Tanrı'yı, ruhu, bedeni vs. birçok kavramı yeniden anlamlandırmak durumundadır. İkbal'in yaratılışçı evrim anlayışı özellikle onun Tanrı, nübüvvet ve ahiret gibi temel inanç konularındaki bakış açılarını da derinden etkilemektedir. Bu sonu olmayan hayat yolculuğunda hayvanlar da insanlar gibi tekâmül sürecine tabidir. Mikro âlemden makro âleme bütün varlık egolarla doludur ve her ego bir aşamaya geçmenin savaşı içindedir. Evrimsel sürecin bütün ufuk sınırlarında her varlık kendi egosunu devam ettirecek, kimliğini koruyacaktır. En büyük ego olan Tanrı böylece varlıklara bir imkân vermiştir. Dolayısıyla egoların bir son durağı olamayacağı gibi Tanrıda yok olmaları da söz konusu değildir. Her ego, kimliğini koruduğu bu var olma savaşının, gelişme arzusunun coşkunluğu içinde akıp gidecektir. İnsana irade serbestliği vererek risk alan Tanrı da bu yaşam coşkusunun içindedir.

İkbal, evrim teorisi bağlamında mücadeleci yaşam felsefesi ve irade özgürlüğünün Tanrının iradesini sınırlandırması sorununu adalet ve hikmet ilkeleriyle aşmaya çalışmaktadır. Hikmeti gereği Tanrı kendi iradesini sınırlandırmıştır. Evrimci bakış açısının ortaya çıkardığı tek sorun bu değildir. Özgür ve mücadele etmeye mahkûm olan insanın bu yaşam tarzı cennette dahi devam edecektir. Evrimci düşüncede yaşamın coşkunluğunu ve sevincini gören İkbal açısından cennet dahi bir dinlenme ve mükâfat alma yeri olamazdı. Daha doğrusu cennetin bir mekân değil bir hal olduğu varsayımından hareketle insanın gelişimini sağlayacak yolculuğu burada da devam edecektir. Oldukça radikal bir görüş olan bu cennet tasavvurunun dinî argümanlarla ispatı zor görünse de İkbal'in yaratıcı evrim felsefesine dayanan bitmeyen tekâmül anlayışı onu böyle bir yorum yapmaya götürecektir. 


\section{Kaynakça}

Abdulhakim, Halife. "Mevlânâ Celâleddin Rûmî”. çev. Yusuf Ziya Cömert. İslâm Düşüncesi Tarihi. ed. M. M. Şerif - Mustafa Armağan. 3/ 43-63. İstanbul: İnsan Yayınları. 1990.

Abdulhakim, Halife. "Muhammed İkbâl". çev. Yusuf Ziya Cömert. İslâm Düşüncesi Tarihi. ed. M. M. Şerif - Mustafa Armağan. 4/401-421. İstanbul: İnsan Yayınları, 1991.

Adıvar, Adnan. Tarih Boyunca İlim ve Din. İstanbul: Remzi Kitabevi, 2000.

Albayrak, Ahmet. “ikbal'de Dinamik İnsan Anlayışı”. Dîvân Illmî Araştırmalar 3/5 (1998/2), 241-254.

Aydın, Mehmet S. "Muhammed İkbal'in Felsefesinde İnsan". Ankara Üniversitesi İlahiyat Fakültesi Dergisi 29/1 (1987), 83-106.

Aydın, Mehmet S. "Süreç (Proses) Felsefesinin Işı̆̆ında Tanrı-Âlem İlişkisi”. Ankara Üniversitesi Illahiyat Fakültesi Dergisi 27/1 (Ağustos 1986), 31-87.

Aydın, Mehmet S. "Genel Değerlendirme". Muhammed İkbal Kitabı Uluslararası Muhammed İkbal Sempozyumu Bildirileri. 219-222. İstanbul: İstanbul Büyükşehir Belediyesi Kültür İşleri Daire Başkanlığı Yayınları, 1997.

Aydın, Mehmet S. "ikkbal'in Felsefesinde Allah Âlem İlişkisi” Muhammed İkbal Kitabı Uluslararası Muhammed İkbal Sempozyumu Bildirileri. 108-114. İstanbul: İstanbul Büyükşehir Belediyesi Kültür İşleri Daire Başkanlığı Yayınları, 1997.

Azmî, M. Yusuf. “ikkbal'de İnsan Kavramı”. çev. Mustafa Alıcı. İkbal’in Düşünce Dünyası. ed. Ahmet Albayrak. 183-191. İstanbul: İnsan Yayınları, 2004.

Bayrakdar, Mehmet. İslâm'da Evrimci Yaratılıs Teorisi. İstanbul: İnsan Yayınları, 1987.

Bergson, Henri. Yaratııı Tekâmül. çev. Mustafa Şekip Tunç. İstanbul: MEB Yayınları, 1947.

Bilmen, Ömer Nasuhî. Muvazzah İlm-i Kelâm. İstanbul: Ravza Yayınları, 2013.

Cengiz, Yunus. Doğa ve Öznellik Câhiz’nn Ahlâk Düşüncesi. İstanbul: Klasik Yayınları, 2015.

Çelik, İsa. Muhammed İkbal'in Tasavvufi Düşüncesi. İstanbul: Kaknüs Yayınları, 2004.

Çetin, Rabiye. “Tanzimat'tan Günümüze Kelam'1 Yenileme Çalışmaları I”. Dini Araştırmalar 16/42 (Ocak-Haziran 2013), 9-38.

Darwin, Charles. Türlerin Kökeni. çev. Öner Ünalan. İstanbul: Evrensel Basım Yayınları, 2009.

Doğan, Atila. Osmanlı Aydınları Ve Sosyal Darwinizm. İstanbul: Küre Yayınları, 2005.

Ferruh, Ömer A. “íhvân-1 Safa”. çev. İlhan Kutluer. İslâm Düşüncesi Tarihi. ed. M. M. Şerif - Mustafa Armağan. 1/327-349. İstanbul: İnsan Yayınları, 1991.

Fığlalı, Ethem Ruhi. Bâbîlik ve Bahâîlik. Ankara: Türkiye Diyanet Vakfı Yayınları, 1994.

Halifat, Sekban. “ikbal'in İhya Projesinin Analizi”. Muhammed İkbal Kitabı Uluslararası Muhammed İkbal Sempozyumu Bildirileri. 154-197. İstanbul: İstanbul Büyükşehir Belediyesi Kültür İşleri Daire Başkanlığı Yayınları, 1997. 
İbn Miskeveyh, el-Fevzü'l-Asğar, çev. Emrah Alagaş - Mehmet Zahit Sezer, İstanbul: Endülüs Yayınları, 2020.

İkbal, Cavid. “Cavid İkbal'in Açılış Konuşması”. Muhammed İkbal Kitabı Uluslararası Muhammed İkbal Sempozyumu Bildirileri. 18-27. İstanbul: İstanbul Büyükşehir Belediyesi Kültür İşleri Daire Başkanlığ1 Yayınları, 1997.

İkbal, Muhammed. İslâm Felsefesine Bir Katkı İran'da Metafizik ìlimlerin Tekâmülü. çev. Cevdet Nazlı. İstanbul: Külliyat Yayınları, 2017.

İkbal, Muhammed. Câvidnâme. çev. Annemarie Schimmel. İstanbul: Kırkambar Yayınları, 1999.

İkbal, Muhammed. Cebrail'in Kanadı. çev. Ahmet Kızılkaya. İstanbul: Kırkambar Yayınları, 2000.

İkbal, Muhammed. Esrar ve Rumuz. haz. Ali Nihad Tarlan. İstanbul: Sufi Kitap, 2005.

İkbal, Muhammed. Hareket Zili. çev. Celal Soydan. Ankara: Hece Yayınları, 2019.

İkbal, Muhammed. İslâm'da Dinî Düşüncenin Yeniden İnşası. çev. Rahim Acar. İstanbul: Timaş Yayınları, 2014.

İkbal, Muhammed. Makaleler. çev. Celal Soydan. Ankara: Hece Yayınları, 2017.

İkbal, Muhammed. Mektuplar. çev. Halil Toker. İstanbul: Kaknüs Yayınları, Birinci Basım, 2002.

İkbal, Muhammed. Şarktan Haber (Zebûr-i Acem Peyam-ı Maşrık). çev. Ali Nihad Tarlan. İstanbul: Sufi Yayınları, 2006.

İzzetbegoviç, Aliya. Doğu ve Batı Arasında İslâm. çev. Salih Şaban. İstanbul: Nehir Yayınları, 2006.

Kaya, Mahmut. İslâm Filozoflarından Felsefe Metinleri. İstanbul: Klasik Yayınları, 2003.

Şehzad Kayser. “ỉkbâl'in İslâm Kültürü Üzerine Eleştirel Bir Yaklaşım”. çev. Mehmet Süheyl Ünal. İkbal' in Düşünce Dünyası. der. Ahmet Albayrak. 263-279. İstanbul: İnsan Yayınları, 2004.

Khatoon, Jamila. İkbal'in Felsefe Sisteminde Tanrı İnsan ve Kâinat. çev. Celal Türer. İstanbul: Üniversite Kitabevi Yayınları, 1963.

Mason, Stephen F. Bilimler Tarihi. çev. Umur Daybelge. Ankara: Türk Tarih Kurumu Yayınları, 2013.

Nietzsche, Friedrich. Güç İstenci. çev. Sedat Umran. İstanbul: Birey Yayıncılık, 2002.

Özervarlı, M. Sait. Kelâmda Yenilik Hareketleri. İstanbul: İSAM Yayınları 1998.

Öztürk, Mustafa. "Çağdaşlık ve Çağdaş Dönem Kur'an Yorumlarına Genel Bir Bakış”. İslâmiyât 7/4 (Ekim-Aralık 2004), 71-94.

Schimmel, Annemarie. Peygamberâne Bir Şair ve Filozof Muhammed İkbal. çev. Senail Özkan. İstanbul: Ötüken Yayınları, 2007.

Soydan, Celal. İkbâl'e Dair. Ankara: Hece Yayınları, 2016.

Taslaman, Caner. Evrim Teorisi felsefe ve Tanrı. İstanbul: İstanbul Yayınevi, 2009.

Timuçin, Afşin. Felsefe Sözlüğü. İstanbul: Bulut Yayınları, 2002. 
Ülken, Hilmi Ziya. Yeni Zamanlar Felsefesi, İstanbul: İş Bankası Yayınları, 2016.

Vahidüddin, Syed. “Muhammed İkbal'in İslâm'a Yaklaşımı Üzerine Tenkitçi Bir Değerlendirme”. çev. Ünver Günay. İkbal'in Düşünce Dünyası. ed. Ahmet Albayrak. 247-261. İstanbul: İnsan Yayınları, 2004.

Yiğit, Fevzi. Metafizik ve Evrim, İstanbul: Önsöz Yayıncllık, 2021, 